\title{
Substance P-and Opioid-Immunoreactive Structures in Olfactory Centers of the Cat: Adult Pattern and Postnatal Development
}

\author{
PETRA WAHLE, CLAUDIA SANIDES-KOHLRAUSCH, GUNDELA MEYER, \\ AND JOACHIM LUBKE \\ Max-Planck-Institut für Biophysikalische Chemie, Am Faßberg, D-3400 Göttingen, \\ Federal Republic of Germany
}

\begin{abstract}
Substance $\mathbf{P}$ (SP)-ir and opioid-ir structures were studied in the cat main olfactory bulb (MOB), accessory olfactory bulb (AOB), and olfactory peduncle. In the MOB, the opioid-ir and the majority of the SP-ir neurons belong to the granule cell type. SP-ir granule cells reside in the deeper granule cell layer, whereas opioid-ir granule cells reside in the superficial granule cell layer, internal plexiform, and mitral cell layer. Many granule cells are observed in the external plexiform and glomerular layer. Other granule cells were found in the bulbar/peduncular white matter, the taenia tecta, and the genu of the corpus callosum. A new substance P-ir cell type was identified in the glomerular layer. This cell type was also identified by using the technique of intracellular injection of Lucifer Yellow. The cell type corresponds neither to the external tufted type nor to the short axon cell types described so far.

The AOB resembles the MOB with respect to large numbers of SP-ir and opioid-ir granule cells. In addition, a few opioid-ir neurons, probably superficial mitral cells, were found in the glomerular layer. The AOB is surrounded by islands of immunoreactive granule cells, which connect to the granule cell layer by extremely long processes.

Opioid-ir and SP-ir beaded axons pass through the olfactory peduncle terminating on granule cells, and ascend as far as the glomerular layer. All subdivisions of the anterior olfactory nucleus (AON) contain immunoreactive terminal fields. Afferent fibers and terminal plexuses derive from a population of immunoreactive neurons located predominantly in the region of the septo-olfactory junction. They have large somata. Their axons form recurrent collaterals, some of which run rostrally in the peduncular white matter. Others ascend caudally towards the septal region. The fibers seem to remain ipsilaterally, since the olfactory limb of the anterior commissure and the commissure proper are devoid of SP-ir and opioid-ir fibers.

During development SP and opioid immunoreactivity were found only in differentiated granule cells. The peptides were not detectable in migrating or immature granule cells, as identified in Golgi-impregnated material. The granule cell population largely develops during postnatal life. The number of opioid-ir granule cells increases slowly and continuously, reaching the adult level not before the sixth postnatal month. Strikingly, SP-ir granule cell number increases fast and reaches a transient peak during the second month. Thereafter it declines ( $40 \%$ decrease) to the adult density, which is similar to that of opioid-ir granule cells.
\end{abstract}

Key words: main and accessory olfactory bulb, peduncle, morphology, afferent innervation, Lucifer Yellow injection

The chemoarchitecture of the mammalian olfactory bulb has received much attention. Most studies aimed at identifying possible transmitters and modulators in the bulbar cell types were originally described by using the Golgi method (Halász and Shepherd, '83; Macrides and Davis, '83, for review). Several studies have already described opioid-ir and substance $\mathrm{P}$ (SP)-ir structures in $\mathrm{MOB}^{1}$ and

${ }^{1}$ A complete list of abbreviations precedes Figure 1.
AOB (Ljungdal et al., '78; Bogan et al., '82; Burd et al., '82; Davis et al., '82; Baker, '86; Matsutani et al., '88, '89). The data reported are divergent with respect to the expression of opioid immunoreactivity in periglomerular cells (compare Matsutani et al., '88, '89) and the morphological characterization of opioid-ir neurons in the EPL and in the bulbar/peduncular white matter (Bogan et al., '82; Davis et 
al., '82; Macrides and Davis, '83). Also, findings on the cell types expressing SP are controversial, since SP-ir granule and tufted cells have been described in some reports, but not in others by using immunohistochemistry (external tufted and no granule cells: Burd et al., '82; Davis et al., '82; Baker, '86; mitral, external tufted, and granule cells: Matsutani et al., '88; only granule cells: Matsutani et al. '89; no cells: Ljungdal et al.,'78) and in situ hybridisation (external tufted, mitral and granule cells: Warden and Young, '88; no cells: Harlan et al., '89). Results differ also with regard to the presence (Davis et al., ' 82 ) or absence (Bogan et al., '82) of opioid-containing afferents. SP-ir afferents have been described only in the hamster (Davis et al., '82). Controversial results are generally explained as species differences. Indeed, the pattern of neuropeptide expression differs between rat and guinea pig (Matsutani et al., ' 88 , '89), although both species belong to the order Rodentia.

In the present study we describe SP-ir and opioid-ir cell types in the MOB and $\mathrm{AOB}$ of the cat, a carnivore species, applying immunohistochemistry supplemented by Golgiimpregnation and intracellular injection of Lucifer Yellow. In addition, we analyzed the morphology and terminal pattern of SP-ir and opioid-ir afferents in MOB and AON, identifying one possible cell population of origin, and developmental changes in the SP-ir and opioid-ir interneuron systems.

\section{MATERIAL AND METHODS}

Our material consisted of 27 cats raised in the Institute's animal colony. The immunohistochemical analysis was carried out in 19 animals of the following postnatal ages: postnatal day (P) 0, P 3 (2 animals), P 10, P 11, P 15, P 17, P 23, P 24, P 25, P 32, P 48, P 60 (2 months), 3.5 months, 5.5 months, 8 months, 1 year, 2 years, and 3 years. The animals were deeply anesthetized with sodiumpentobarbitone (Nembutal $^{\mathrm{R}} ; 60 \mathrm{mg} / \mathrm{kg}$ bodyweight) and perfused through the heart with $0.9 \% \mathrm{NaCl}$ and $1 \%$ sucrose in $0.05 \mathrm{M}$ phosphate buffer, $\mathrm{pH} 7.4$, followed by $4 \%$ paraformaldehyde, $1 \%$ sucrose, and $0.2 \%$ picric acid in $0.1 \mathrm{M}$ phosphate buffer, $\mathrm{pH}$ 7.4. Blocks of the basal forebrain including the olfactory bulbs were soaked over night in $20 \%$ sucrose for cryoprotection. The blocks were cut with a vibratome or freezing microtome into $80 \mu \mathrm{m}$ thick sections of frontal, parasagittal, or horizontal plane. They were collected in $0.1 \mathrm{M}$ sodium phosphate buffer, $\mathrm{pH} 7.4$. The free-floating sections were subsequently processed for immunocytochemistry. All washing steps were carried out with TBS (0.05 M Tris-HClbuffer [pH 7.6] containing $125 \mathrm{mM} \mathrm{NaCl}, 2 \%$ sucrose, and $0.1 \%$ BSA). Antibody penetration was enhanced by incubation in $0.2 \%$ Triton X-100 in TBS for $1 / 2-1$ hour. Nonspecific binding sites were blocked by incubation in $3 \%$ normal swine serum in TBS (NSwS) for 1 hour.

The following primary antisera were used: The antiserum against substance $P$, raised in rabbit, was kindly provided by Profs. Tohyama and Hamaoka, Osaka, Japan (for specification see Takatsuki et al., '83); optimal staining results were obtained by a dilution of $1: 1,000$. The monoclonal antibody $3 E 7$ raised in mouse, was provided by Prof. A. Herz and Dr. C. Gramsch, Munich, Federal Republic of Germany; the antibody was raised against the $\mathrm{N}$-terminus of $\beta$-endorphin, but cross-reacted with several peptides of the opiate family, including enkephalins (for specification see Gramsch et al., '83); optimal staining results were obtained by a dilution of 1:300. Incubation in the primary antisera was carried out at room temperature for at least 12 hours.

The material was processed according to the PAP method (secondary antibodies and PAP-complex purchased from DAKO, Hamburg). The PAP method was carried out as previously described (Sanides-Kohlrausch and Wahle, '90a,b). In addition, material from the youngest stages were stained with the streptavidin-biotin-peroxidase labeling method (ABC method, kit purchased from DAKO, Hamburg, and used as recommended by the supplier). We found that the ABC method revealed more labeled cells in the youngest stages (first postnatal week). Thereafter, both methods yielded the same result. Controls: Staining was totally abolished either when $100 \mu \mathrm{g}$ of the peptide (Substance P; Met ${ }^{5}$-enkephalin, synthetic, Sigma) was added to $1,000 \mu \mathrm{l}$ antiserum 30 minutes prior to incubation, or by omitting the primary antiserum.

Three animals aged P3 (2) and P6 were processed for Golgi impregnation. After perfusion under deep anesthesia with $2 \%$ glutaraldehyde and $2 \%$ paraformaldehyde in $0.1 \mathrm{M}$ cacodylate buffer, $\mathrm{pH} 7.3$, blocks of the basal forebrain and the olfactory bulb were impregnated in $2.5 \%$ glutaraldehyde, $3.5 \%$ potassium dichromate, and $1 \%$ chloralhydrate followed by $0.75 \%$ silver nitrate (Meyer, ' 83 ). The blocks were cut by hand with a razor blade into sections of about $100 \mu \mathrm{m}$ thickness, dehydrated in graded alcohols, soaked in propylenoxide, and mounted in Epon-Araldite resin between a slide and a coverslip.

One cat aged 2 months was prepared for the LYFtechnique (intracellular injection of Lucifer Yellow in neurons in fixed brain slices) as described in detail by Buhl and Lübke ('89). Perfusion was carried out as for immunohistochemistry. The tissue was cut on a vibratome into $100 \mu \mathrm{m}$ thick parasagittal sections which were collected in $0.1 \mathrm{M}$ phosphate buffer and prestained with the fluorescent dye DAPI $(0.001 \%$ diamidino-2-phenyl-indol in phosphate buffer, pH 7.4) in order to visualize cell nuclei. Under visual control single cells were filled iontophoretically with Lucifer Yellow (LY, a 5\% aqueous solution). LY was subsequently photo oxidized for 30 minutes in the presence of

\section{Abbreviations}

$\begin{array}{ll}\text { AC } & \text { anterior commissure } \\ \text { ACC } & \text { nucleus accumbens } \\ \text { AOB } & \text { accessory olfactory bulb } \\ \text { AON } & \text { anterior olfactory nucleus } \\ \text { AONd } & \text { anterior olfactory nucleus, dorsal division } \\ \text { AONv } & \text { anterior olfactory nucleus, ventral division } \\ \text { C } & \text { cerebral cortex } \\ \text { CA } & \text { nucleus caudatus } \\ \text { CC } & \text { corpus callosum } \\ \text { EPL } & \text { external plexiform layer } \\ \text { EP } & \text { ventricular ependyma } \\ \text { FL } & \text { fiber layer } \\ \text { GL } & \text { glomerular layer } \\ \text { GRL } & \text { granule cell layer } \\ \text { IPL } & \text { internal plexiform layer } \\ \text { LV } & \text { lateral ventricle } \\ \text { LOT } & \text { lateral olfactory tract } \\ \text { ML } & \text { mitral cell layer } \\ \text { MOB } & \text { main olfactory bulb } \\ \text { OLT } & \text { olfactory tubercle } \\ \text { SUB } & \text { subependymal layer } \\ \text { TT } & \text { taenia tecta } \\ \text { wm } & \text { white matter } \\ \text { I } & \text { layer I (molecular layer) } \\ \text { II/III } & \text { layer II/III (pyramidal/polymorph layer }\end{array}$




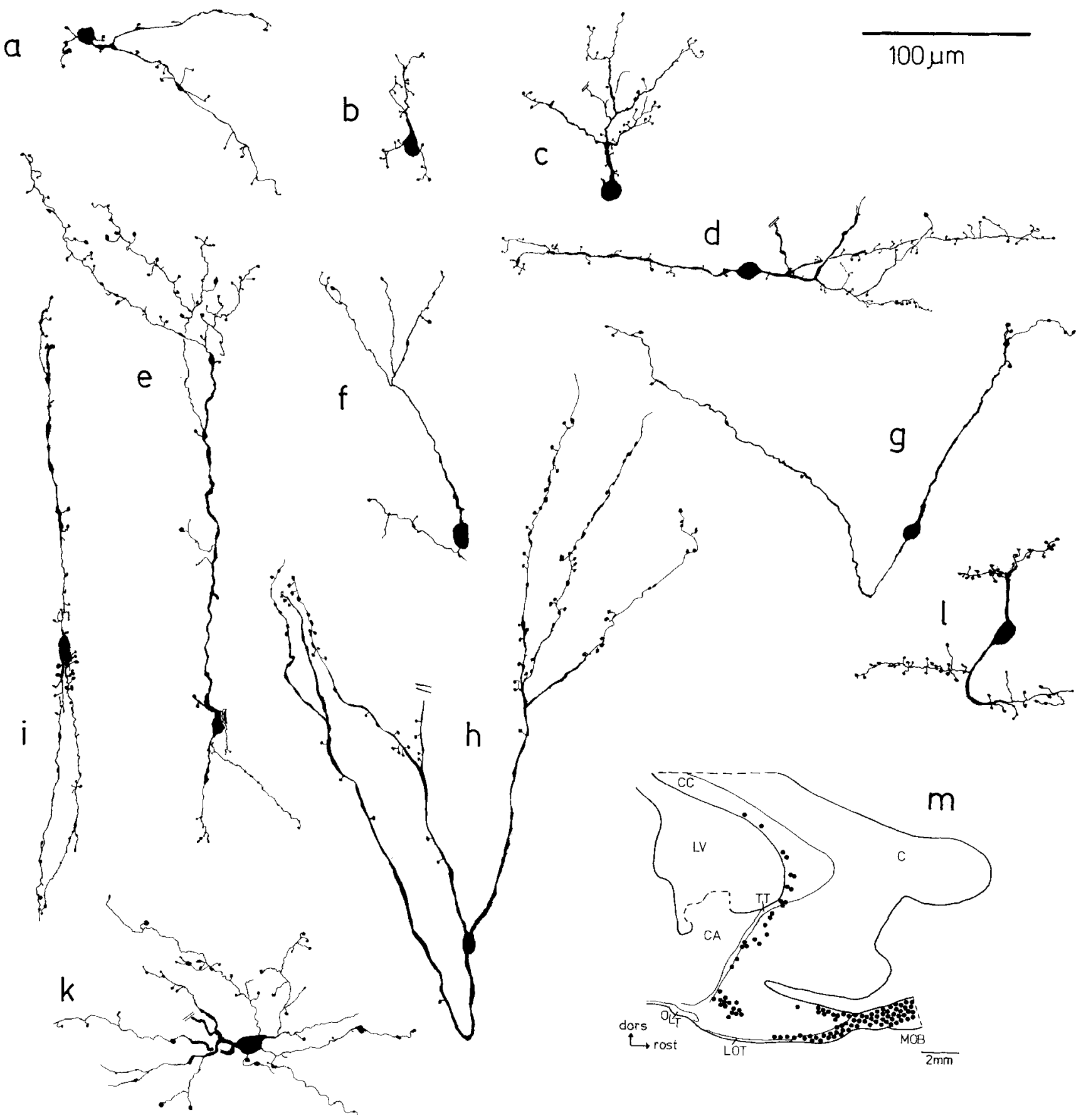

Fig. 1. Camera lucida drawings of SP-ir (e-k) and opioid-ir (a-d,l) granule cells; typical granule cell of the GRL (e); atypical granule cells of the GL (a-c), EPL (d,f,g), ML (h), bulbar/peduncular white matter $(\mathrm{l}, \mathrm{k})$, genu of the corpus callosum (i). m: Parasagittal section through the basal forebrain. Black dots indicate the distribution of retrobulbar granule cells.

$0.05 \%$ DAB under UV-illumination (Zeiss filter combination BP 436/FT 460/LT 470). The sections were mounted and dried. The $\mathrm{DAB}$ reaction product was intensified with $1 \%$ osmiumtetroxide in $0.1 \mathrm{M}$ phosphate buffer. Then, the sections were dehydrated, cleared, and coverslipped. In the immunohistochemical material, anatomical centers were identified according to the atlas of Berman and Jones ('82) in alternate sections stained with $0.2 \%$ thionine. In addi- tion, thionine stained serial sections of the basal forebrain of five adult cats aged 1 to 2 years were analyzed. The morphology of neurons was analyzed with a Leitz Dialux 20 microscope equipped with a camera lucida. Immunoreactive neurons were reconstructed by drawings made at a final magnification $\times 800$. Overview drawing of the innervation pattern were made at a final magnification of $\times 50$. The position of SP-ir and opioid-ir neurons, respectively, was 

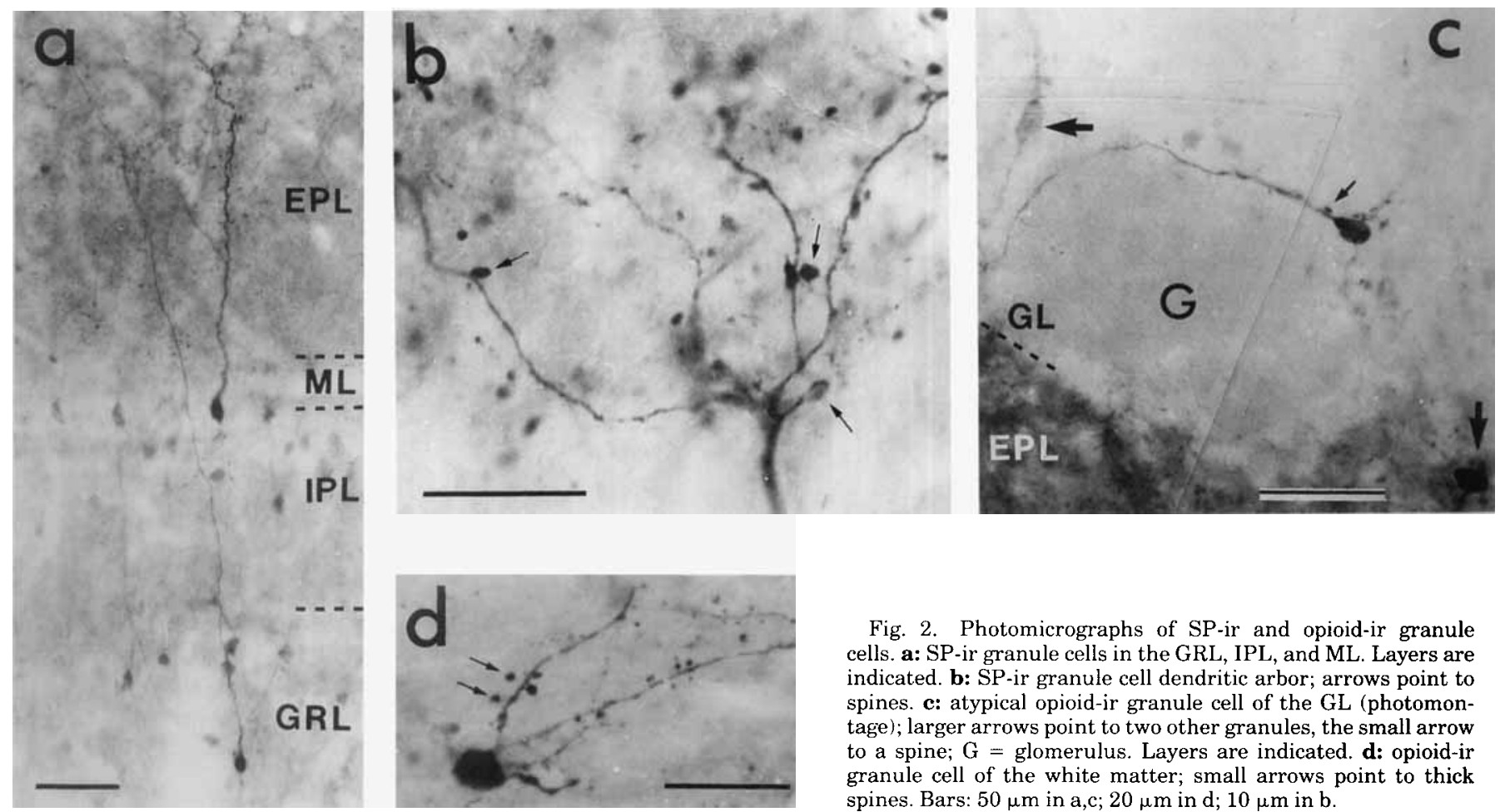

charted with an XY-plotter attached to the stage of the microscope. The number of neurons per section or layer was counted from these plots.

We use the term "opioid-ir" for structures stained with the antibody $3 \mathrm{E} 7$ which is known to recognize several peptides of the opiate family (Gramsch et al., '83). The term SP-ir is used for structures displaying tachykinin-like immunoreactivity, since cross-reactivity of the antiserum with other members of the tachykinin family cannot be excluded. The anatomical terminology of our previous reports (Sanides-Kohlrausch and Wahle, '90a,b) is used.

\section{RESULTS}

The report is organized into two parts. In the first part we will describe the morphology of SP-ir and opioid-ir elements as observed in animals older than 3 months. In the second part we focus on the postnatal development of immunoreactive structures.

\section{Morphology of immunoreactive structures}

Granule cells. Many immunoreactive neurons were stained in a Golgi-like fashion allowing the classification of neuronal types. In the cat MOB granule cells, as classified in many earlier studies (for example, Price and Powell, '70; Schneider and Macrides, '78), were abundant in material stained with the anti-opioid antibody and the SP antiserum. The somata were ovoid and small (diameter about 8 $\mu \mathrm{m})$. They gave rise to one thick primary dendrite ascending perpendicularly or slightly obliquely towards the EPL (Figs. 1e, 2a). At the level of the ML or the deep EPL it branched up into the terminal dendritic arbor. The terminal arbors remained in the EPL. Somata and dendritic trees were covered with spines consisting of long pedicles and very thick knobs (Figs. 1, 2b). The EPL always appeared as the most intensely stained layer due to the accumulation of immunoreactive processes and spine knobs (Fig. 2a). The spiny basal dendrites of granule cells were thinner, short, and generally unbranched (Fig. 1e). Axons were never observed.

A subset of SP-ir and opioid-ir neurons resembled granule cells with regard to soma size and shape, spine morphology, and the lack of an axon. Their dendritic ramification patterns, however, differed from the typical granule cells described above. We termed these neurons "atypical granule cells." They were found in the ML, EPL, and GL of the MOB (Figs. 1a-d,f-h, 2c) as well as scattered in the bulbar/peduncular white matter (Figs. 1k,1, 2d), the taenia tecta, and even the genu of the corpus callosum (Fig. 1i). Figure $1 \mathrm{~m}$ indicates the distribution of atyical granule cells in retrobulbar centers.

The atypical granule cells found in the ML and EPL lacked a primary apical dendrite. Instead, two or more dendrites extended obliquely into the EPL (Fig. 1g,h). Atypical granule cells located at the EPL/GL border arranged horizontally (Fig. 1d). Others had extremely shortened dendrites. Atypical granule cells in the GL were found only in opioid-ir material. They were located in the glomerular intersticies or at the surface of glomeruli. The dendritic patterns were extremely variable. Some neurons gave rise to very short dendrites which were oriented perpendicularly to the MOB surface, and were restricted to the glomerular intersticies (Fig. 1b). Others had longer dendrites extending along the surface of a glomerulus (Figs. $1 \mathrm{a}, \mathrm{c}, 2 \mathrm{c})$. The atyical granule cells in the bulbar/peduncular white matter often lacked polarity. The dendritic pattern was multipolar or bitufted (Figs. 1k,l, 2d). In non-bulbar centers, e.g., the corpus callosum, atypical granules were bipolar to bitufted, and arranged parallel to the predominant fiber orientation. 

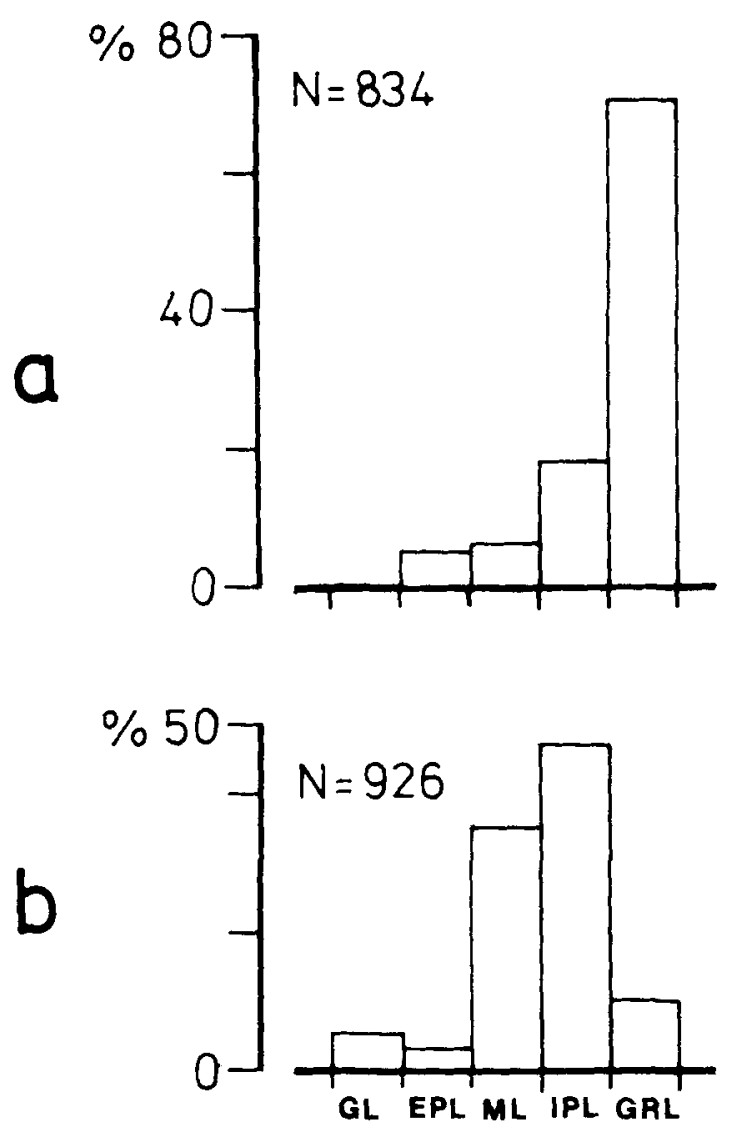

Fig. 3. Number of SP-ir (a) and opioid-ir granules (b) per MOB layer counted from a single frontal section. $\mathrm{N}=$ total cell number per section. Section area was $13 \mathrm{~mm}^{2}$ and section thickness $80 \mu \mathrm{m}$. Abscissa: $\mathrm{MOB}$ layers; ordinate: cells per layer in \% of $\mathrm{N}$. Note the different proportion of SP-ir and opioid-ir granules in GRL, IPL, and ML.

Granule cells in opioid-ir and SP-ir material displayed the same morphological variety and frequency of occurence. However, they were differentially distributed in the MOB layers. Figure 3 shows the result of cell counts performed in the different layers. It was evident that the majority of the SP-ir granule cell somata was located in the GRL. In contrast, the majority of opioid-ir granule cell somata was found in the IPL and ML, with fewer neurons in the GRL.

Neurons in the glomerular layer. In addition to the opioid-ir atypical granule cells in the GL, we observed SP-ir neurons which neither resembled granule cells nor other cell types described so far in the GL. Their frequency of occurrence was very low. They were generally encountered in groups of three to seven neurons associated with a single glomerulus. Per section, only one to six glomeruli displayed such a cell group as documented in Figures 4a, 5a. Other neurons of this type are shown in Figures $4 \mathrm{~b}, 5 \mathrm{~b}, \mathrm{c}$. The somata were located at the surface of glomeruli. They were ovoid and small (diameter of about $10 \mu \mathrm{m}$ ). Stout primary dendrites ran into a glomerulus branching into a dendritic tree, which did not fill the entire glomerulus. Other dendrites extended into the glomerular intersticies. The dendrites of higher order were filiform. All dendrites were non-spiny and non-varicose. The SP-ir neurons associated with glomeruli gave rise to an axon.
The low frequency of occurrence indicated that either the cell type is rare or the majority of the cells cannot be stained with the anti-SP antiserum. We examined our Golgi material, but could not identify a cell type of comparable morphology and distribution. We therefore employed the recently developed technique of intracellular injection of Lucifer Yellow in fixed tissue (Buhl and Lübke, '89) aiming to fill neurons at the glomerular surfaces. We succeeded in reproducibly filling neurons of two types.

The first type corresponded to external tufted cells (Figs. $4 \mathrm{c}, 5 \mathrm{~g}, \mathrm{~h}$ ), as shown by Cajal ('11). The soma diameter was about $15 \mu \mathrm{m}$. They gave rise to a very stout primary dendrite entering the glomerulus. The primary dendrite did not arborize before it had reached the glomerulus. Then, many fan-like thin secondary dendrites arose. They were confined to the glomerulus. Their distal ramifications were filiform and prominently beaded. They filled the glomerulus with a dense network.

The second type (Fig. 5d-f) strikingly resembled the SP-ir neurons associated with glomeruli described above. The somata were ovoid and small (about $10 \mu \mathrm{m}$ in diameter). A primary dendrite ran into a glomerulus branching up into finer dendrites of higher order. Other dendrites extended in the glomerular intersticies. The dendrites were non-spiny and non-beaded. The neurons gave rise to an axon. Of the neurons shown, two (Fig. 5e,f) were filled while injecting the external tufted cells (see legend to Fig. 4), and one (Fig. 5d) was injected directly.

Neurons in the accessory olfactory bulb. The SP-ir and the opioid-ir staining pattern in the cat $\mathrm{AOB}$ were very similar. The majority of the immunoreactive somata was located in the GRL. Somata were ovoid (diameter about 10 $\mu \mathrm{m})$ and gave rise to two or more dendrites which ran in all directions, eventually bending to and probably terminating in a dense ir plexus covering the EPL/ML/IPL (Fig. 6d,e). Distal ramifications were difficult to follow in the terminal plexus. Single dendritic fragments were covered with spines bearing very thick knobs (Fig. 6b). We classified the neurons as granule cells. The plexus produced by the distal dendritic ramifications and spines of the immunoreactive granule neurons was most dense subjacent to the GL. It decreased gradually towards the white matter. Ovoid holes appearing in the plexus (Fig. 6d) turned out to be large somata, probably of the $\mathrm{AOB}$ mitral cells, when viewed with Nomarsky optics.

Only in the opioid-ir material did a few neurons occur in the GL. They had round or ovoid somata about $12 \mu \mathrm{m}$ in diameter. Their stout primary dendrites entered glomeruli. Within the glomerulus, they branched into filiform beaded processes producing a very complex network (Fig. 6a,c). Patches of high immunoreactivity were generally observed along the periphery of the AOB. They were termed "AOB islands," since they consisted of granule cells and their dendritic plexus. The cat AOB was surrounded by such islands, which were stained as intensely as the EPL/ML/ IPL of the AOB proper (Fig. 6f,g). The AOB islands were best identified in SP stained material, and occurred medially, laterally, and caudally to the AOB (Fig. 10a-c,h,i). Long processes of granule cells bridge over considerable distances to reach the AOB proper (Figs. $6 \mathrm{~g}, 10 \mathrm{~h}$ ).

$S P$-ir and opioid-ir fibers in $M O B, A O B$, and $A O N$. A dense innervation by SP-ir and opioid-ir fibers was identified in the MOB. Fibers were heavily beaded. In the GRL they accumulated around the granule cell clusters (Figs. 7c, 8a). Thick varicosities were found in close proxim- 

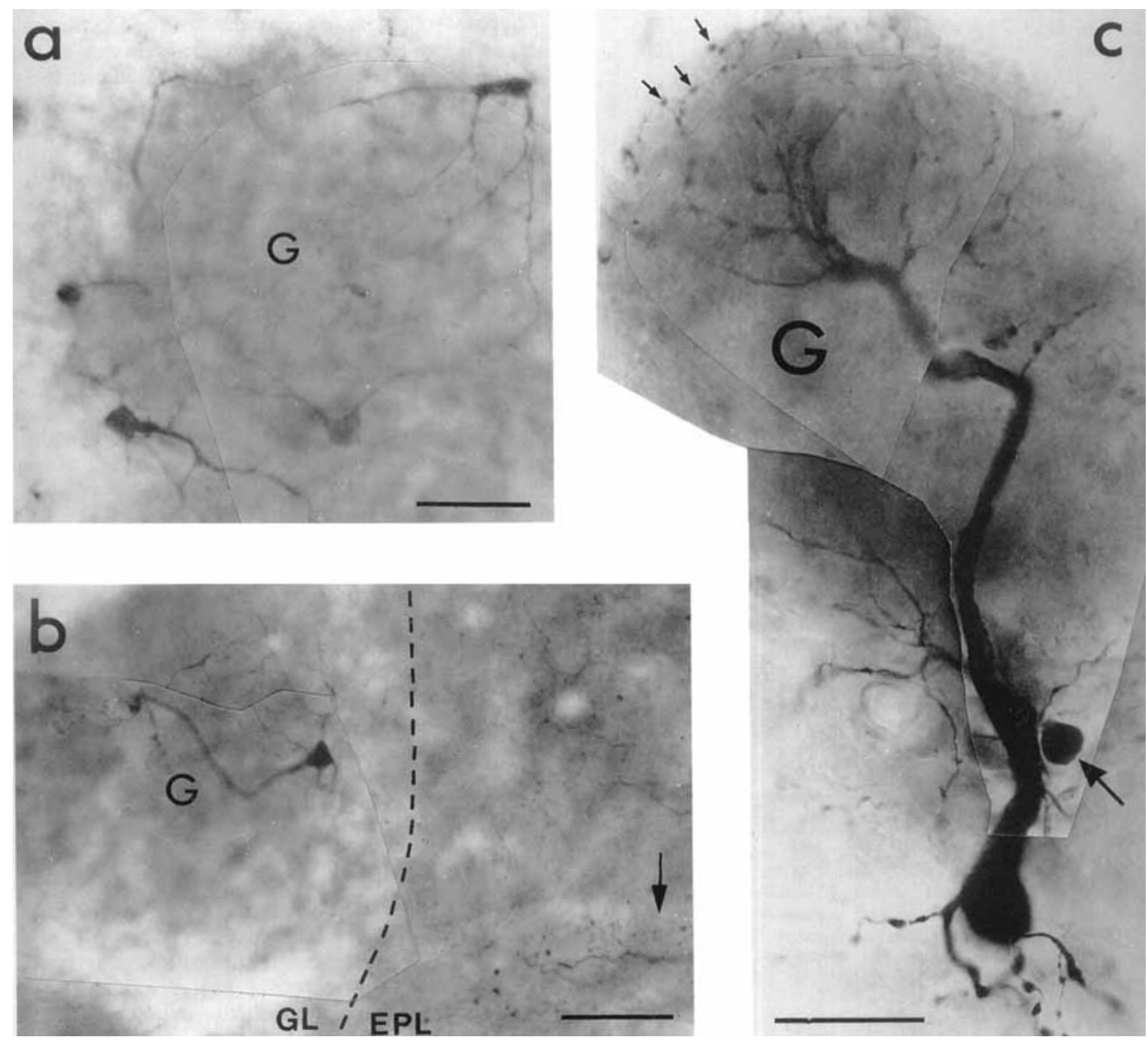

indicate its dendritic varicosities. Large arrow points to a neuron of the

Fig. 4. Photomontages of SP-ir and LY-injected neurons of the GL. a: SP-ir neurons grouped around a single glomerulus. b: Single SP-ir neuron. Layers are indicated. Arrow points to a spiny granule cell dendrite in the EPL. c: LY-injected external tufted cell. Small arrows

ity to immunopositive and immunonegative granule cell somata and dendrites suggesting synaptic contacts (Fig. $7 \mathrm{~d}, \mathrm{e})$. Most contacts were of an en passant type. Fibers passed through IPL and ML into the EPL (Fig. 7a). They might ramify in the EPL (Fig. 7b). Fibers ascended further into the GL (Fig. 7a,b). They were largely confined to the glomerular intersticies, and varicosities were observed close to small immunonegative somata in the periglomerular region (not shown). Beaded axons also invaded at least the deep aspect of the $\mathrm{AOB}$ granule cell layer, but due to the
$\mathrm{SP}$-ir type filled while injecting the external tufted cell. $\mathrm{G}=$ glomerulus. Bars: $50 \mu \mathrm{m}$ in $\mathrm{a}, \mathrm{b} ; 30 \mu \mathrm{m}$ in $\mathrm{c}$.

high immunoreactivity they could not be followed into more superficial layers.

In addition, plexuses of thick beaded fibers forming complex axonal arbors were present in the AON (Fig. 8c-e), but were not confined to its cytoarchitectonic subdivisions (Berman and Jones, '82). Other axonal arbors were identified in the piriform cortex (Figs. $7 \mathrm{~g}, 8 \mathrm{f}$ ). The plexuses represented terminal ramifications of quite thick, smooth, or slightly beaded axons (e.g. Fig. 8d). Boutons seemed to contact unstained cell bodies.
Fig. 5. Camera lucida drawings of SP-ir $(a-c)$ and LY-injected neurons $(d-h)$. a: Reconstruction of the group shown in Figure 4a. b: Neuron of Figure $4 b$. Another SP-ir neuron is shown in c. $d-f$ : LY filled neurons of the SP-ir type. d: This neuron was directly injected. e,f: The two cells were filled while injecting external tufted cells (g,h). The soma of neuron e was localized in close vicinity to the dendrite (asterisk) of cell $\mathrm{g}$. The soma of cell $\mathrm{f}$ was close to the soma of cell $\mathrm{h}$. Arrows point to axons. g,h: LY filled external tufted cells. Note the size difference and the dense network of beaded distal dendritic ramifications compared to the smooth profiles of the SP-ir neuronal type. 
ง

$\searrow$

$r$

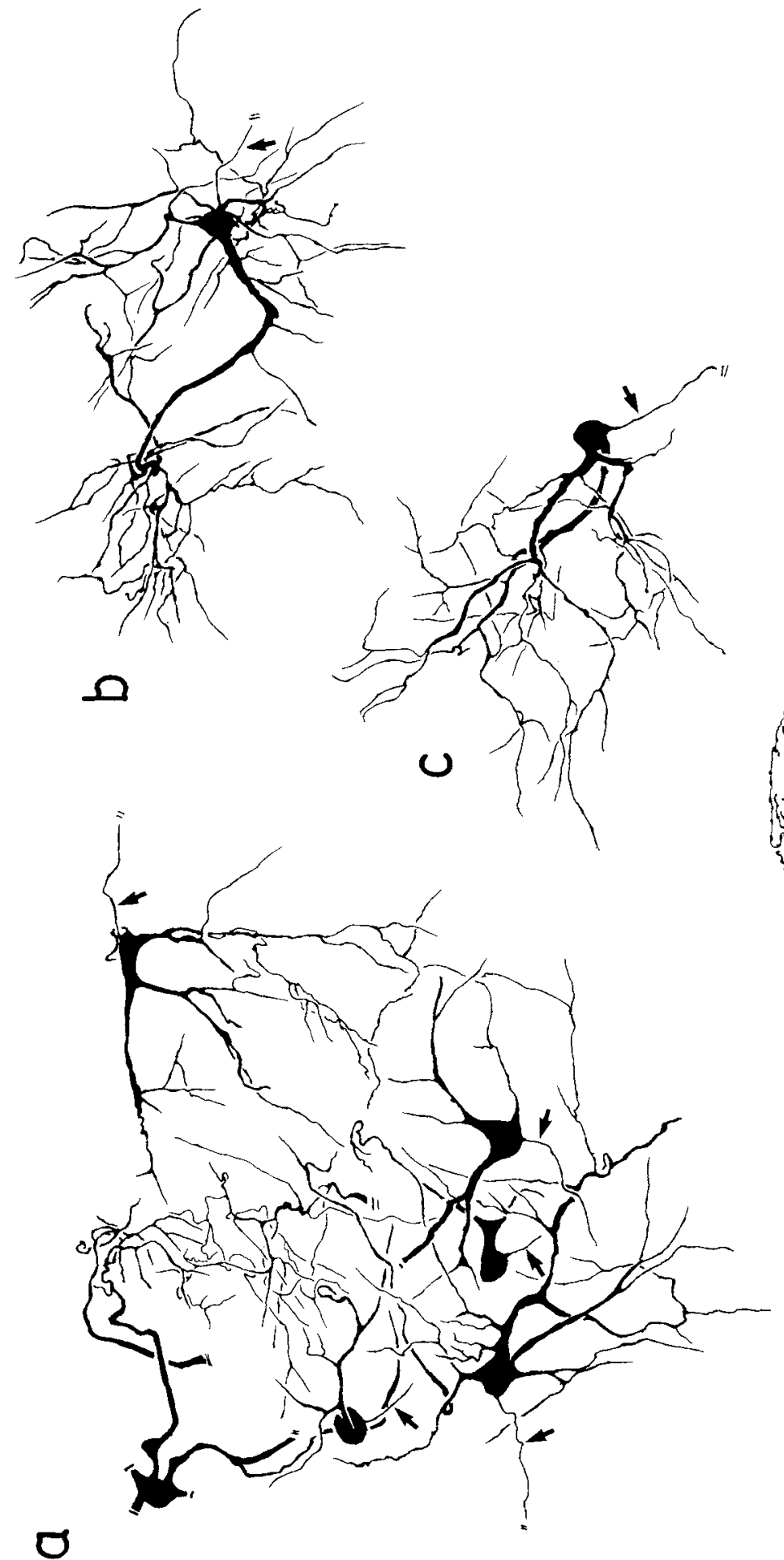

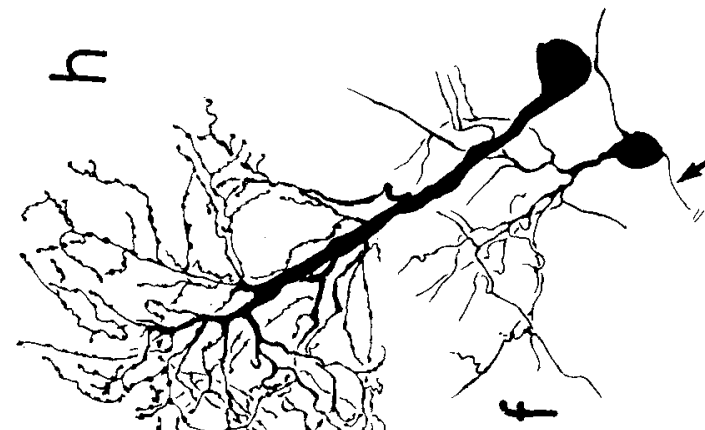

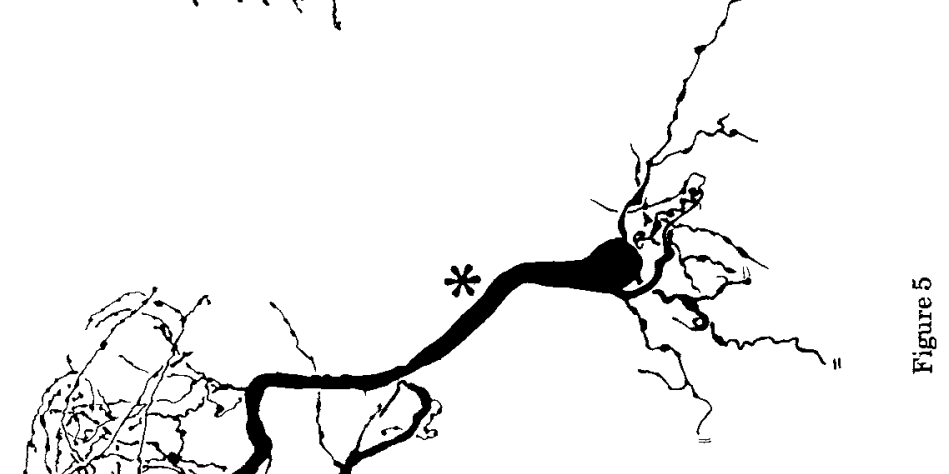

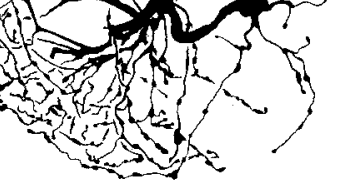

O)

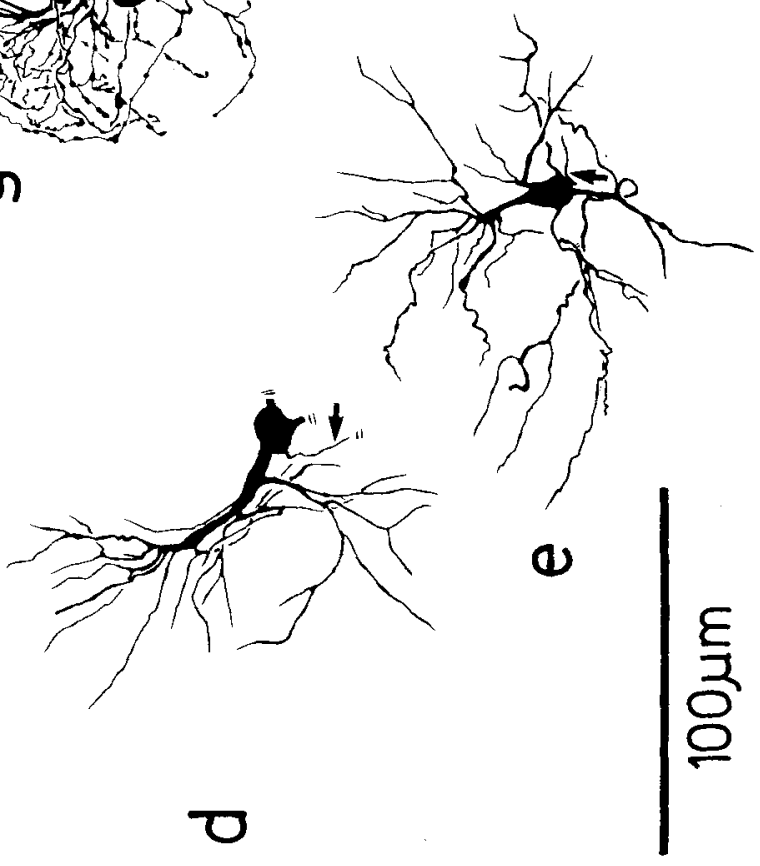



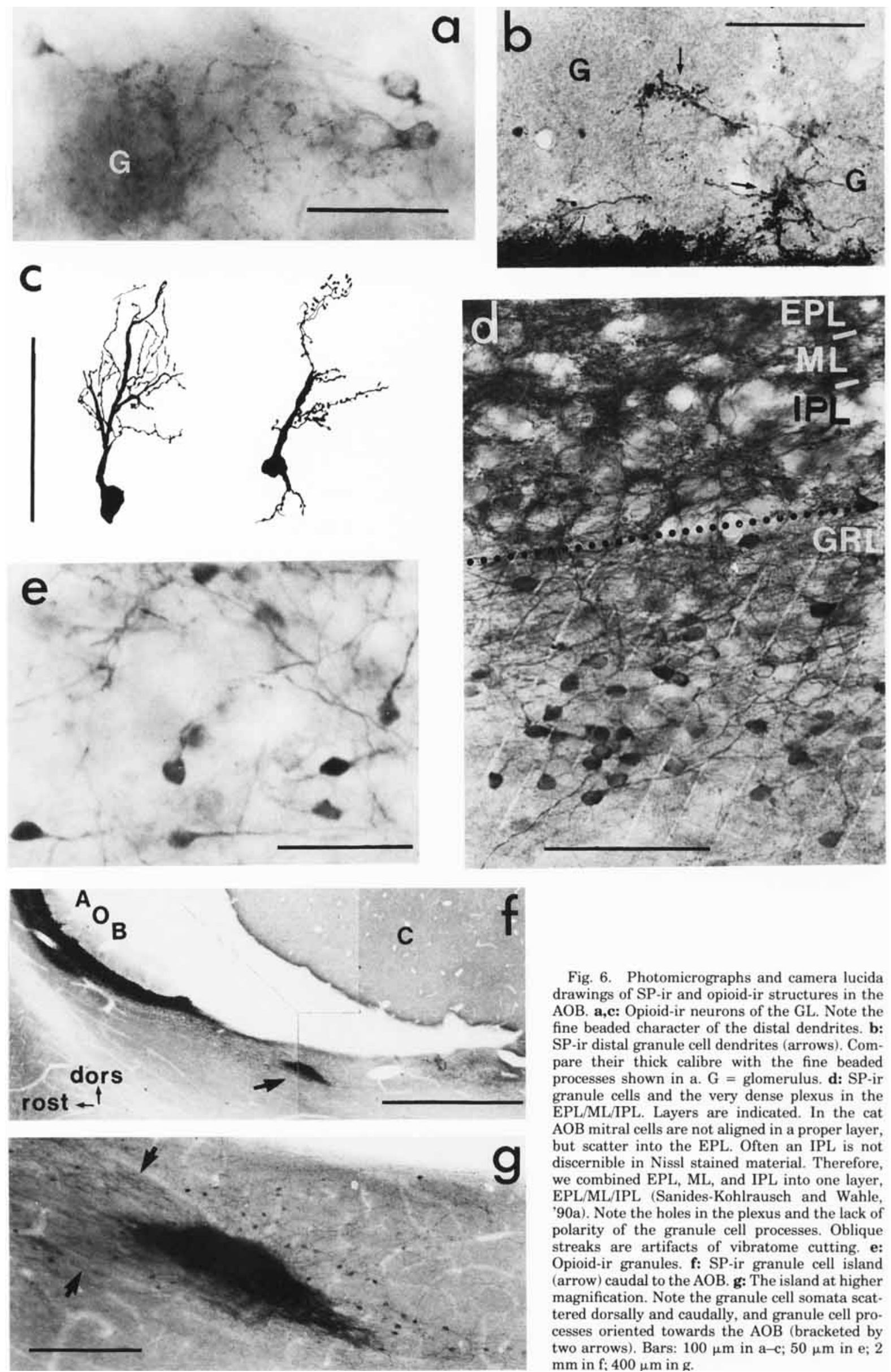

Fig. 6. Photomicrographs and camera lucida drawings of SP-ir and opioid-ir structures in the AOB. a,c: Opioid-ir neurons of the GL. Note the fine beaded character of the distal dendrites. $\mathbf{b}$ : SP-ir distal granule cell dendrites (arrows). Compare their thick calibre with the fine beaded processes shown in a. $\mathrm{G}=$ glomerulus, $\mathbf{d}$ : $\mathrm{SP}$-ir granule cells and the very dense plexus in the EPL/ML/IPL. Layers are indicated. In the cat $\mathrm{AOB}$ mitral cells are not aligned in a proper layer, but scatter into the EPL. Often an IPL is not discernible in Nissl stained material. Therefore, we combined $\mathrm{EPL}, \mathrm{ML}$, and IPL into one layer, EPL/ML/IPL (Sanides-Kohlrausch and Wahle, '90a). Note the holes in the plexus and the lack of polarity of the granule cell processes. Oblique streaks are artifacts of vibratome cutting. e: Opioid-ir granules. f: SP-ir granule cell island (arrow) caudal to the AOB. g: The island at higher magnification. Note the granule cell somata scattered dorsally and caudally, and granule cell processes oriented towards the AOB (bracketed by two arrows). Bars: $100 \mu \mathrm{m}$ in a-c; $50 \mu \mathrm{m}$ in e; 2 $\mathrm{mm}$ in $\mathrm{f}: 400 \mu \mathrm{m}$ in $\mathrm{g}$. 
In the AON, layers II/III generally were densely innervated. Fibers extended into the molecular layer (Fig. 7f), where they followed horizontal courses (Fig. 9a,c). Fibers were not homogeneously distributed in the AON. The camera lucida reconstructions of the olfactory peduncle (Fig. 9a,c) revealed that they accumulated in patches. The highest innervation density was observed in dorsomedial parts of the AON, in sections in which the AOB was prominent (Fig. 10a-g). In basal parts of the AON, posterior portions were more densely innervated than anterior portions (e.g. Figs. 9a, 10f,g). Serial sagittal reconstructions revealed that the innervation density decreased in the lateral AON, and became even thinner towards the piriform cortex. Here, narrow columns of about 200 to $300 \mu \mathrm{m}$ width consisting of fibers and terminals connected the white matter and layer I (Figs. 9c, 10h,i). Such finger-like extensions were not seen in the piriform cortex proper.

The course of the afferent axons was charted from serial sagittal sections (Fig. 10c-f). We observed fibers in the bulbar white matter, which gave side branches entering the granule cell layer (Fig. 8b). Single fibers were traced further caudally in the white matter and the deep aspect of layers II/III of the AON. We could follow some fibers to the posterior parts of the AON. Others ascended in the white matter close to the lateral ventricle or close to its ependymal zone (Fig. 10d) and some extended caudally to the border of the striatum (Fig. 10e). The fibers were not organized into a distinct bundle. Further, they were not continuous with the olfactory limb of the anterior commissure and the anterior commissure proper (as the NPY-ir fiber system of the cat bulbar/peduncular white matter described recently; Sanides-Kohlrausch and Wahle, '90a). Rather, the SP-ir and opioid-ir fibers accumulated in the so-called septo-olfactory junction (SOJ, according to Berman and Jones, '82, plates 100 and 111).

In the same region, but also scattered in the bulbar/ peduncular white matter, SP-ir and opioid-ir neurons were observed (Fig. 7h). Their distribution is given in Figure 10. Somata were about $25 \mu \mathrm{m}$ in diameter. The neurons were multipolar, but dendrites were only faintly labeled. Smooth axons arose from the somata and branched into a number of collaterals, directing anteriorly, posteriorly and into overlying cellular layers of the AON. Single branches were followed for more than $1,000 \mu \mathrm{m}$ into either direction (Fig. $9 \mathrm{~b})$. Other collaterals ascended towards the septal region.

\section{Postnatal development of MOB and AOB}

The kitten MOB expanded considerably during postnatal life (Fig. 11c). When the MOB area was plotted over age (Fig. 11d), only a slight increase in size during the first week was recognizable. It is followed by a steep increase during the following 3 weeks. The bulbar area doubled during the first postnatal month, and the bulbs continued to grow slowly during the following month. Adult-like proportions were reached by the end of the second postnatal month, and size differences in adults seemed to be interindividually variable. The ML in Nissl stained material was almost three to four somata deep in material from young kittens, whereas in adult cats the mitral cell somata were organized in a "monolayer" (not shown). The plexiform layers doubled in width (Fig. 13a,b; compare P3-P3a), the granule cell layer expanded, as did the white matter with ongoing myelination.

A prominent feature of the immature MOB was the broad subependymal layer (Fig. 11b,c). It was continuous with the germinal zones along the wall of the olfactory and lateral ventricle, and the remnants of the ganglionic eminence dorsal to the striatum. It became reduced after the sixth postnatal week. Concurrently, the olfactory ventricle became closed in most animals examined. In adults, the presence or absence of an olfactory ventricle was variable between individuals. The subependymal layer consisted of densely packed small cell bodies. Mitotic cells and also pycnotic cells were consistently observed (Fig. 11a). The Golgi-impregnated material of young kittens showed a stream of small cells (Fig. 12a) characterized by a longer, rostrally oriented process tipped by a growth cone (Fig. $12 b)$.

The subependymal layer was devoid of SP-ir and opioid-ir cell bodies at all postnatal ages examined, although many small somata express microtubule associated protein (the neuronal MAP2). All neurons displaying neuropeptide immunoreactivity were located outside the subependymal layer. During the first postnatal week neurons in the MOB granule cell layer were rather faintly labeled by SP and opioid immunohistochemistry. The somata had the size of mature granule cells, and their position indicated a granule cell character. Staining intensity increased, and completely labeled granule cells were encountered from the second week onwards. All granule cells labeled during the first month gave the impression of fairly well differentiated cells. The dendrites were well shaped and bore spines. We did not observe growth cones at dendritic tips. In conclusion, we did not observe features of neuronal maturation in neurons of the granule cells population by using neuropeptide immunohistochemistry. In contrast, MAP2 immunohistochemistry and the Golgi material revealed both well-differentiated granule cells in the MOB as early as P 3 (Fig. 12c) and many undifferentiated granule cells.

We observed pronounced differences in the density of SP-ir and opioid-ir granule cells during development. SP-ir was detectable in granule cells from P 0 onward. The density of SP-ir somata increased rapidly during the first two weeks and remained high until the seventh week. After an about $40 \%$ reduction, the cell density remained constant. Also, some opioid-ir granule cells could be stained as early as P 0. However, their density increased slowly and approached the SP-ir neuron density not before the sixth postnatal month. Equal numbers of cells per plane were then found in adult animals (Fig. 13a-c).

The SP-ir neurons associated with the glomeruli were identified as early as P3, and were fairly well stained. Morphologically, they appeared well differentiated. Their frequency of occurrence was as low as in adult animals.

A few SP-ir and opioid-ir beaded axons have entered the MOB already at $\mathrm{P} 0$, but they were encountered more often during the following days. The fibers frequently bore growth cones (Fig. 12d) even during the second and third week. An adult-like innervation density was eventually reached by the end of the first postnatal month, and a dense innervation persists in older animals.

The postnatal development of SP- and opioid-immunoreactivity in the AOB is shown in Figure 14. In the AOB, a considerable number of SP-ir somata, probably granule cells, was already labeled at P 0 . Also the scattered islands of granules surrounding the $\mathrm{AOB}$ were already present during the first postnatal week. Until P10 the staining intensity of somata and their processes increased, and the terminal plexus in EPL/ML/IPL appeared. Its immunoreactivity increased dramatically (P25 and $3.5 \mathrm{MO}$ panel in Fig. 

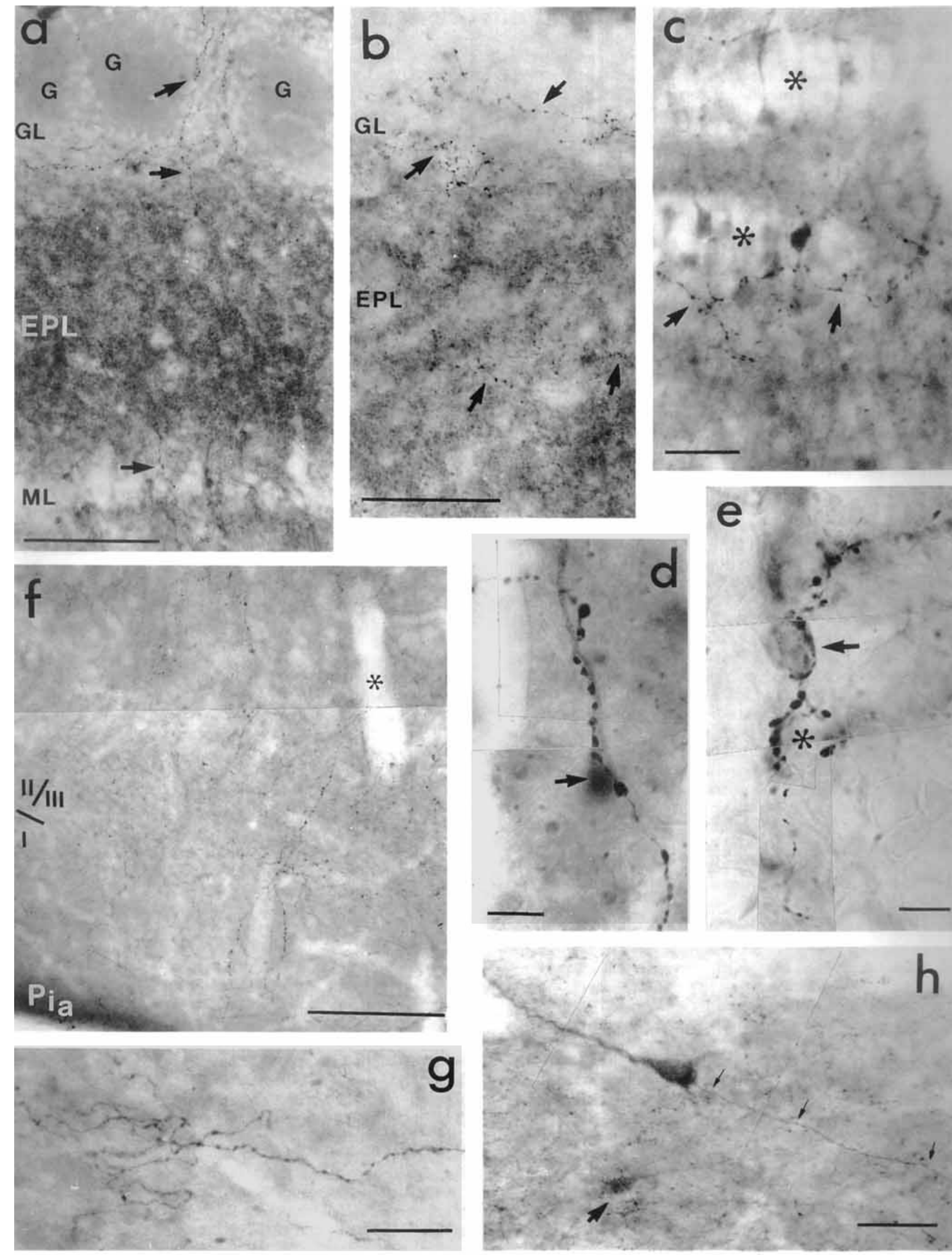

h 
14a) and processes extended into the GL. Such exuberant processes were not observed in older animals. In adults, the plexus is confined to the EPL/ML/IPL.

Opiod-ir granule cells were also present at birth and, as in the MOB, their density and staining intensity increased slowly with age (Fig. 14b). Their density was, however, always lower than the density of SP-ir granule cells. The intensity of the opioid-ir terminal plexus in the EPL/ML/ IPL increased less conspicuously and, in adult animals, was lower than the SP innervation density. We did not observe plexus exuberances in the GL. The opioid-ir neurons of the GL (Fig. 6a,c) were only identified in material from adult cats.

\section{DISCUSSION Granule cells}

The vast majority of opioid-ir and $\mathrm{SP}$-ir neurons in the cat MOB belong to the granule cell type. Opioid-ir granule cells are a common feature of the mammalian MOB (rat: Bogan et al., '82; Matsutani et al., '89; hamster: Davis et al., '82; guinea pig: Matsutani et al., '88). In contrast, SP-ir granule cells are reported only for the guinea pig MOB (Matsutani et al., '89). In the rat, SP-ir appears in granule cells after colchicine pretreatment (Matsutani et al., '88), but not in untreated animals (Ljungdal et al., '78; Shults et al., '84; Baker '86). Results are still controversial, since by using in situ hybridization, Warden and Young ('88) detected tachykinin mRNA containing granule cells, whereas Harlan et al. ('89) did not.

The SP-ir and opioid-ir granule cells represent only subsets of the granule cell population, because only a few cells are labeled in every granule cell cluster. Granule cells are GABAergic interneurons (Ribak et al., '77; Kosaka et al., '85; Gall et al., '87; own observations) and a peptidergic nature can be assumed for part of the population. In other species, a more-or-less complete spatial overlap exists between SP-ir and opioid-ir granule cells (Matsutani et al., '89), and a colocalization of SP and opioid seemed possible. In the cat however, SP-ir and opioid-ir granule cells differ in position, in that opioid-ir granule cells lay in upper GRL, IPL, and even ML, whereas SP-ir granule cells occur deeper in the GRL. This argues for the existence of two neurochemically defined granule cell subtypes.

Granule cells have been divided into three morphological subtypes in rabbit (Mori et al., '83), rat (Orona et al., '83), and mouse (Greer, '87). Type III granule cells in the superficial GRL extend dendrites into superficial half of the

Fig. 7. Photomicrographs of SP-ir and opioid-ir axons in the MOB and olfactory peduncle. a,b: Opioid-ir fibers (indicated by arrows) ascending through the ML and EPL to the GL running through the glomerular intersticies. Layers are indicated. $\mathrm{G}=$ glomerulus. c: Opioid-ir granule cell in a granule cell cluster and opioid-ir axon terminals accumulating around granule cell clusters (arrows; clusters indicated by asterisks). d: Opioid-ir beaded axon in close vicinity to an immunoreactive granule cell dendrite. The soma (arrow) is not in focus. e: Opioid-ir terminals in close vicinity to an immunopositive (arrow) and an immunonegative (asterisk) granule cell soma. f: SP-ir terminal field in AONv. Layers are indicated. Asterisk marks a blood vessel. Note that fibers ascend to layer I. g: Elaborate opioid-ir plexus of the piriform cortex. h: Large SP-ir neuron in the septo-olfactory junction. Small arrows point to the axon, the larger arrow to a retrobulbar gramule cell. $\mathrm{b}, \mathrm{d}-\mathrm{f}, \mathrm{h}$ are photomontages. Bars: $100 \mu \mathrm{m}$ in $\mathrm{a}, \mathrm{b}, \mathrm{f} ; 50 \mu \mathrm{m}$ in $\mathrm{c}, \mathrm{g}, \mathrm{h} ; 10 \mu \mathrm{m}$ in $\mathrm{d}, \mathrm{e}$.
EPL, and are thought to terminate on tufted cells. Type II granule cells are located deeper in the GRL, and arborize in the deeper half of the EPL terminating on mitral cells. Type $I$ is localized in the GRL and arborizes through the whole width of the EPL. Accordingly, in our material opioid-ir granule cells would correspond to type III, while SP-ir granule cells would correspond to type II. However, the EPL does not show the expected two-tiered innervation pattern. Rather, SP- and opioid-immunoreactive dendritic arbors are distributed evenly through the whole width of the EPL. This would characterize all peptidergic granule cells as type $\mathrm{I}$. Therefore, in the cat we propose that SP-ir and opioid-ir granule cells represent two neurochemical subtypes, which do not correspond to the morphological subtypes I, II, or III. A surprising result was the presence of many granule cells that were not located in the GRL proper. A large proportion of opioid-ir granule cells lay in the IPL and even in the ML scattering also into the EPL. Others were present in the GL. We have summarized all dislocated granule cells as "atypical," mainly because their shapes are much more variable, and most of them lack the radially polarized orientation typical of the granule cells of the GRL. Nevertheless, all display granule cell characteristics, e.g., small soma size, spiny dendrites, and lack of an axon (Price and Powell, '70). Therefore, they do not correspond to short axon cells, which have an axon (Schneider and Macrides, '78). The opioid-ir neurons of the cat GL also represent atypical granules, and are not periglomerular cells. This is important to note because in rodents, the majority of opioid-ir neurons in the GL represent periglomerular cells (Davis et al., '82; Bogan et al., '82; Matsutani et al., '89). We labeled the population of periglomerular cells with the antibody $3 E 7$ in the rat MOB for control purposes, and to confirm the results of Bogan et al. ('82) and Matsutani et al. ('88). Many atypical granule cells are also present in retrobulbar regions, displaying dendritic patterns ranging from bipolar to multipolar. They are located in the ventricular zone in which granule cells are generated (Altman, '69; Bayer, '83) and along which granule cells migrate towards the bulb (Kiski, '87; the present study). Despite the ectopic localization, the neurons have the capacity to differentiate and express neuropeptides. Their function and synaptic partners in these non-bulbar structures remain to be elucidated.

\section{SP-ir neurons of the glomerular layer}

The GL of the cat MOB contains SP-ir neurons associated with glomeruli. They do not correspond to any cell type described so far. A peculiar feature was their selective appearance in groups surrounding a single glomerulus. In the first instance it looks like a rare cell type. However, we were able to reproducibly label neurons of the type by injecting Lucifer Yellow into somata in the periglomerular region. This rather suggests that the cell type is as frequent in the GL as external tufted cells. We consider the SP-ir neurons of the cat GL a new cell type. The smooth profile of their dendrites denies any relation to densely spinous periglomerular cells (Pinching and Powell, '71 a,b; Schneider and Macrides, '78). It is unlikely that we failed to label spines, because they can be stained by immunohistochemis. try (Meyer and Wahle, '86) and are filled by the LYF technique (Buhl and Lübke, '89). Further, a correspondence to superficial short axon cells can be excluded. This neuronal class has sparsely spinous dendrites which are restricted to the glomerular interstities (Pinching and 


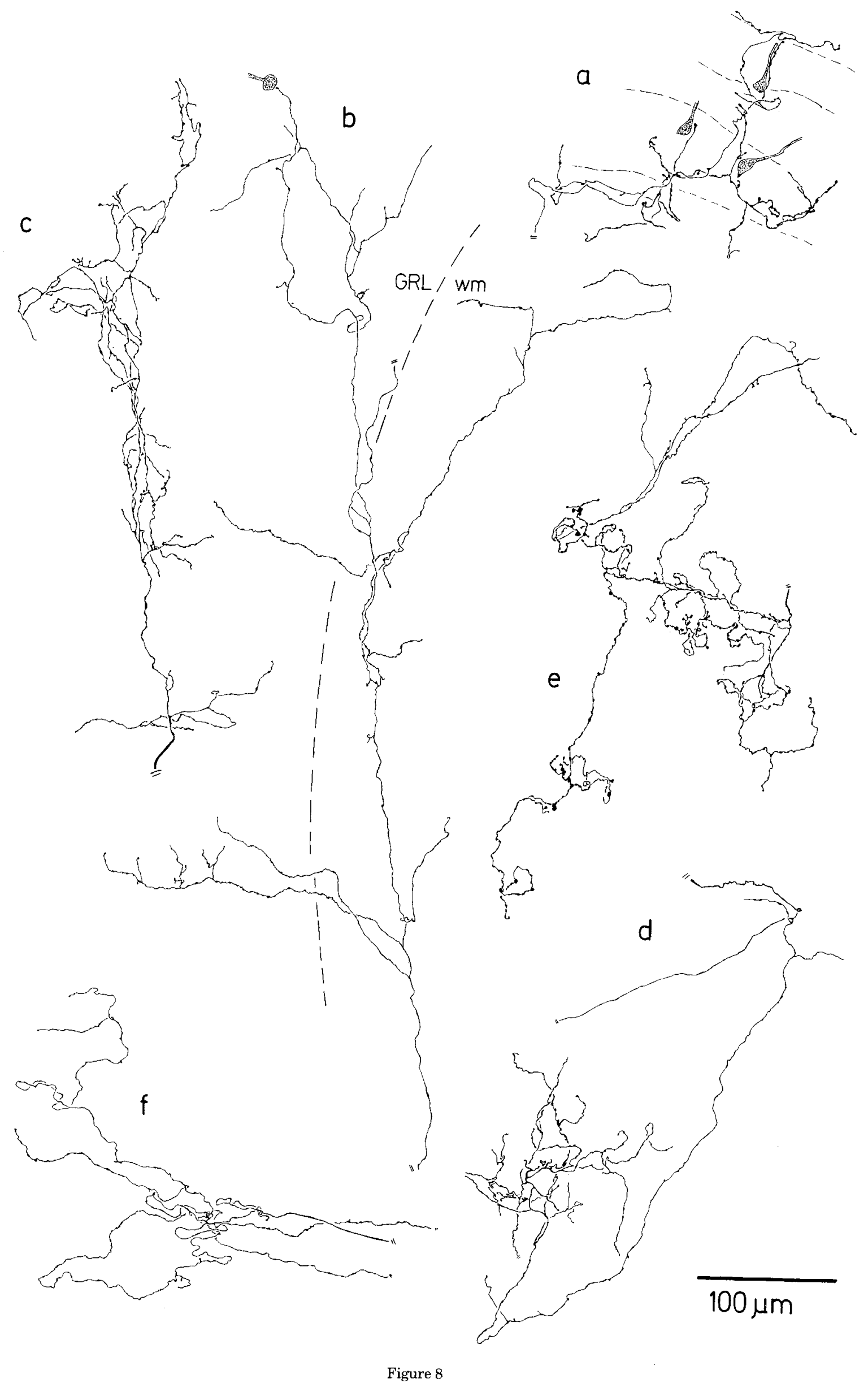


Powell, '71) and extend into the EPL (Schneider and Macrides, '78). It is further evident that the SP-ir neurons do not represent external tufted cells, reported to be SP-ir in the rodent MOB (Burd et al., '82; Davis et al., '82; Baker, '86; Matsutani et al., '88). External tufted cells were unequivocally labeled by our intracellular injections and in the Golgi material, displaying the characteristic features of this type (Cajal, '11). The conspicuous filiform ramifications outlining the inner surface of the glomerulus are evident. None of the numerous morphological variants of external tufted cells documented by Macrides and Schneider ('82) resembles the SP-ir neuron type associated with glomeruli in the GL of the cat.

A disadvantage of the LYF-technique in fixed tissue is that axons cannot be sufficiently filled. The axonal pattern is the most distinctive feature of a neuronal type, and the connectivity of short axon cell types in the periglomerular region is still far from clear. Slice cultures of the MOB and intracellular injection of live cells (Katz, '87) may help to clarify the questions and possibly result in a revised classification of bulbar interneuron types, especially in the group of short axon cells. Intracellular injection of dyes, which allows a high morphological resolution, has been so far applied only for the principal neuron types (Mori et al., '83; Kishi et al., '84).

A peculiar observation was that in some cases neurons of the SP-ir type were filled while injecting an external tufted cell. This could be caused by damaging the dense periglomerular neuropil. Alternatively, it could argue for dye coupling between the two cell types via gap junctions. This possibility, however, should be analyzed at the ultrastructural level.

We consider the SP-ir cell type as frequent and possibly being associated with every glomerulus, since it can be routinely stained with the LYF-technique. However, the SP-ir neurons occur in groups around a few glomeruli, whereas the vast majority of glomeruli has no SPimmunoreactive material in the neurons associated with them. The question is therefore why only some neurons of this type express SP, and why these few cells occur around only a single glomerulus. We suggest that SP is expressed only in those neurons associated with a glomerulus which is either in a stage of formation or in the process of synaptic reorganization. It has been recently claimed that during postnatal development glomeruli are added de novo to the glomerular layer (Purves et al., '89) arranging in between already existing ones. Synaptic reorganization in the glomerular layer is caused by the persistent turnover of olfactory receptor cells and their centripetal projection (Graziadei and Monti-Graziadei, '78; Breipohl et al., '86). The influence of SP on such processes is unclear, but might be explained with the trophic actions of this neuropeptide (see below).

\section{Accessory olfactory bulb}

The cat AOB contains a high number of SP-ir and opioid-ir granule cells, resembling in this aspect the AOB of

Fig. 8. Camera lucida drawings of SP-ir (a-d) and opioid-ir (e,f) axon plexuses in MOB, AON, and the piriform cortex. a: MOB GRL; dashed lines delineate granule cell clusters. Stippled somata are immunoreactive granule cells. b: White matter/GRL border (dashed line). One fiber terminates in close vicinity to a granule cell soma (stippled). c,d: AONv. e,f: Piriform cortex. rat, hamster, and guinea pig (Macrides and Davis, '83; Baker, '86; Matsutani et al., '88, '89).

Besides granule cells, only mitral cells have been identified (Cajal, '11; Golgi method) in the mammalian AOB. Presumed periglomerular cells have been identified in Nissl stained material (Lohman, '63). The opioid-ir neurons in the GL of the cat AOB described in the present study could thus belong to one these types. Macrides and Davis ('83) mentioned faintly labeled opioid-ir mitral cells in the hamster AOB. Therefore, it is possible that the opioid-ir neurons in the GL of the cat $A O B$ belong to the mitral cell class, although their classification was difficult because too few neurons were found. However, we have not been able to identify such faintly labeled mitral cells in the EPL/ML/ IPL, possibly because they are masked by the very dense plexus formed by the opioid-ir granule cell dendrites in this layer. Alternatively, it is possible that the AOB contains neurochemically different subsets of principal neurons (mitral and tufted cells), as does the MOB in rodents. A peculiar feature of the cat $\mathrm{AOB}$ are islands of granule cells scattered around its periphery. We had the impression that they are extensions of the AOB granule cell layer. We have not observed large cell bodies (mitral cells) associated with islands, but it is conceivable that the granule cells of such islands reach the basal dendrites of AOB mitral cells by means of their conspicuously long processes. The cat $A O B$ thus is not the well delineated unit as it is in rodents. Possibly, the different course of the lateral olfactory tract in rodents and carnivores (Switzer et al., '80) accounts for this peculiarity. Nevertheless, with respect to the peptidergic organization, the cat $\mathrm{AOB}$ strikingly resembles the MOB. In both centers, opioid-ir and SP-ir granule cells are present in the deeper layers which receive the terminal plexus of the bulbar/peduncular neuropeptide Y (NPY)-ir projection system (Sanides-Kohlrausch and Wahle, '90a). Like the MOB, the $\mathrm{AOB}$ contains vasoactive intestinal polypeptide/peptide histidine isoleucine-ir Van Gehuchten Cells (SanidesKohlrausch and Wahle, '90b).

\section{Afferent innervation of $\mathrm{MOB}, \mathrm{AOB}$, and $\mathrm{AON}$}

SP-ir and opioid-ir afferents to the MOB were mentioned in earlier reports (Davies et al., '82; Macrides and Davis, '83; Baker, ' 86 ), but have been less well documented than the intrinsic peptidergic neuron systems. Further, the neurons of origin have rarely been identified. We have recently described a NPY-containing neuronal system (Sanides-Kohlrausch and Wahle, '90a). The neurons of origin are distributed in the bulbar/peduncular white matter, and the axons terminate on granule cells in MOB and AOB and diffusely in all subdivisions of the AON. The SP-ir and opioid-ir neuronal type described in the present report is very similar to the NPY-ir neurons with respect to soma size, dendritic pattern, and the initially looping axon. However, the somata were more frequent towards caudal portions of the olfactory peduncle, accumulating in the septo-olfactory junction. We assume that these neurons give rise to at least part of the bulbar and AON afferents described in the present study. This was also suggested for opioid-ir bulbar afferents by Macrides and Davis, ('83). In contrast to the NPY-ir system, the anteriorly projecting SP-ir and opioid-ir axons terminate not only in the GRL, but ascend as far as the GL, possibly innervating the periglomerular region. Furthermore, in the AON SP-ir and opioid-ir terminal plexuses are much denser than the 

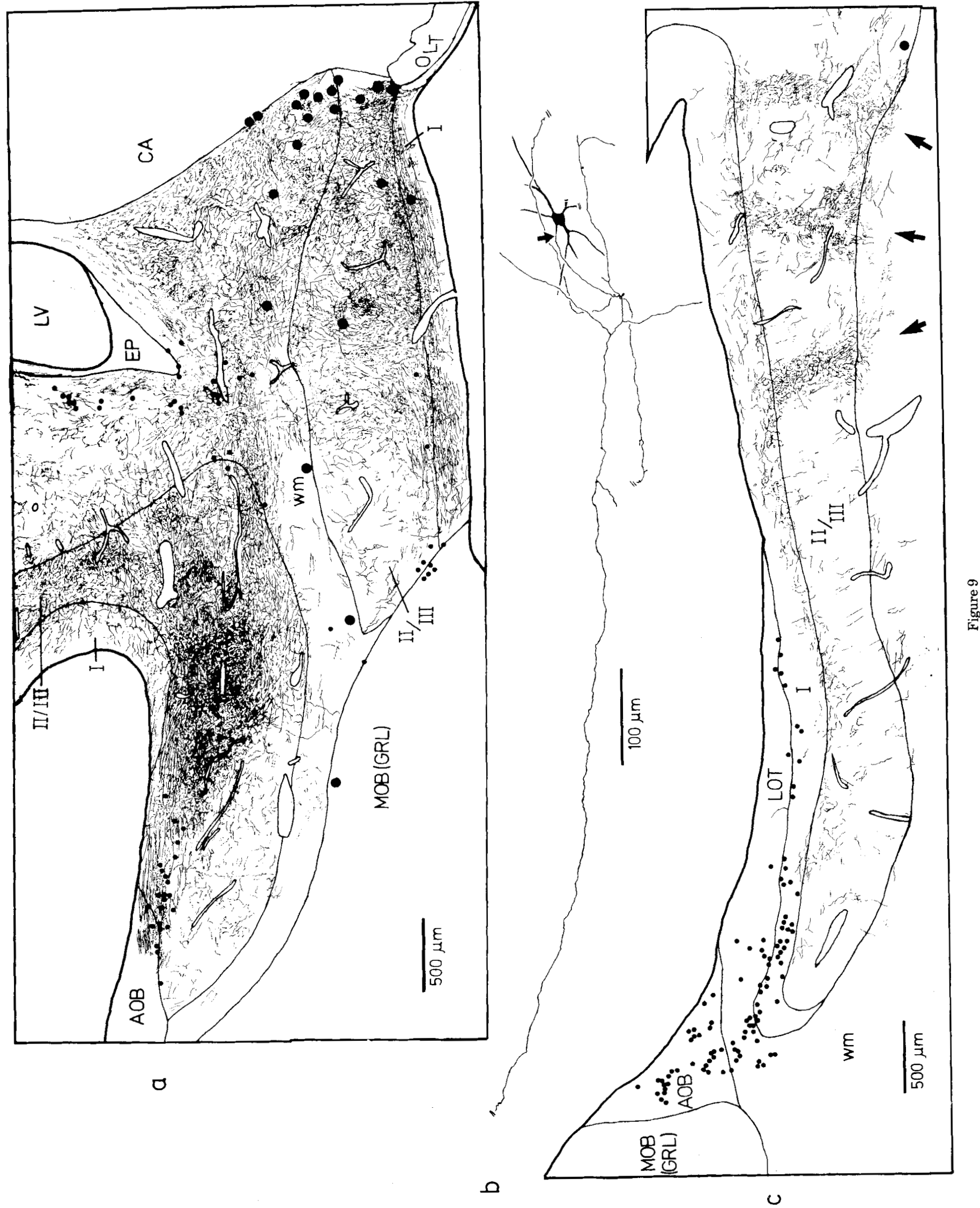


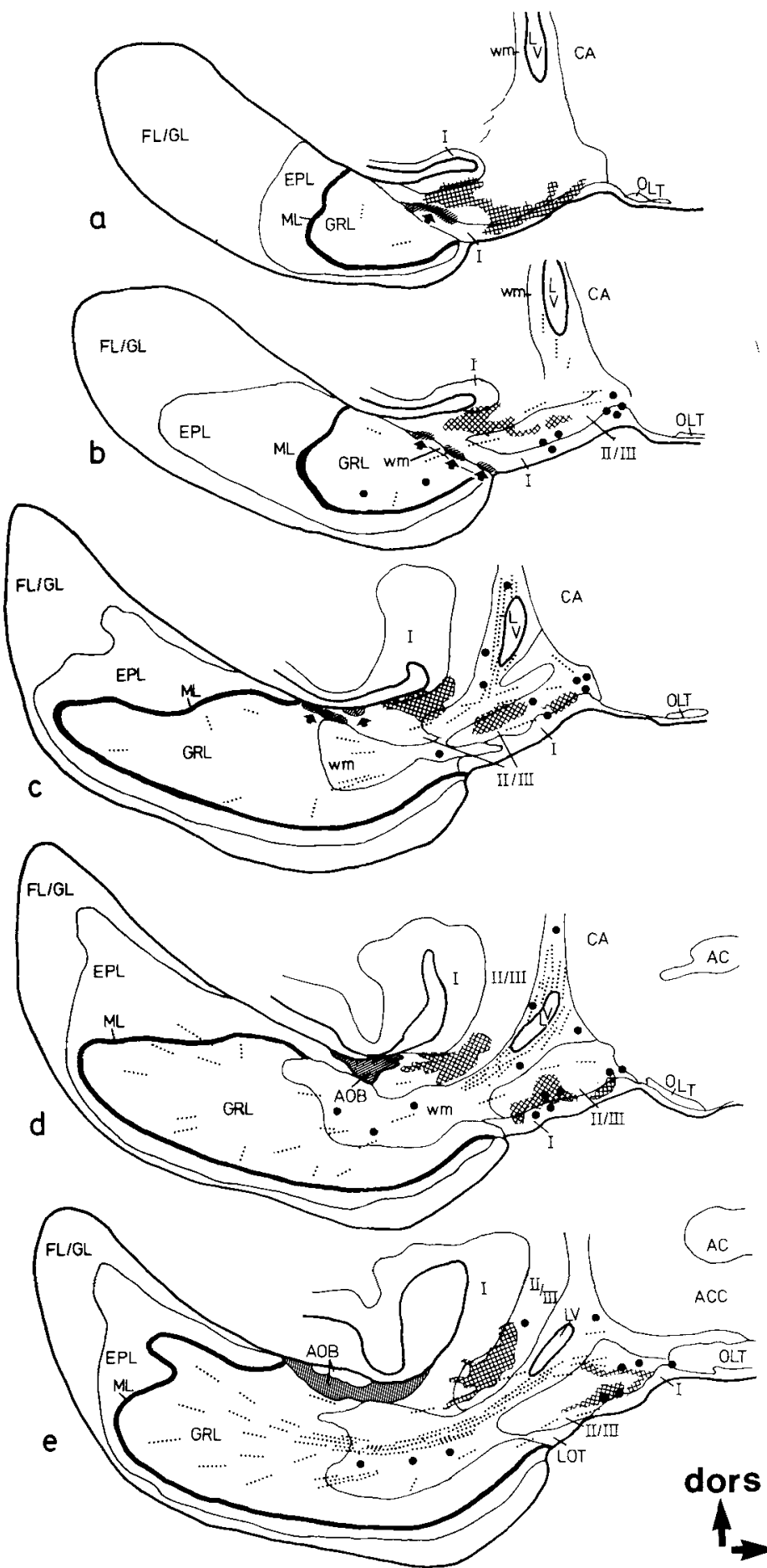

Fig. 10. A series of representative parasagittal sections through the olfactory bulb and peduncle, drawn from SP-ir material, demonstrating the distribution of bulbar and retrobulbar afferents, terminal fields, and neurons. Sections are arranged from medial (a) to lateral (i). Every large dot represents two immunoreactive neurons of the type shown in

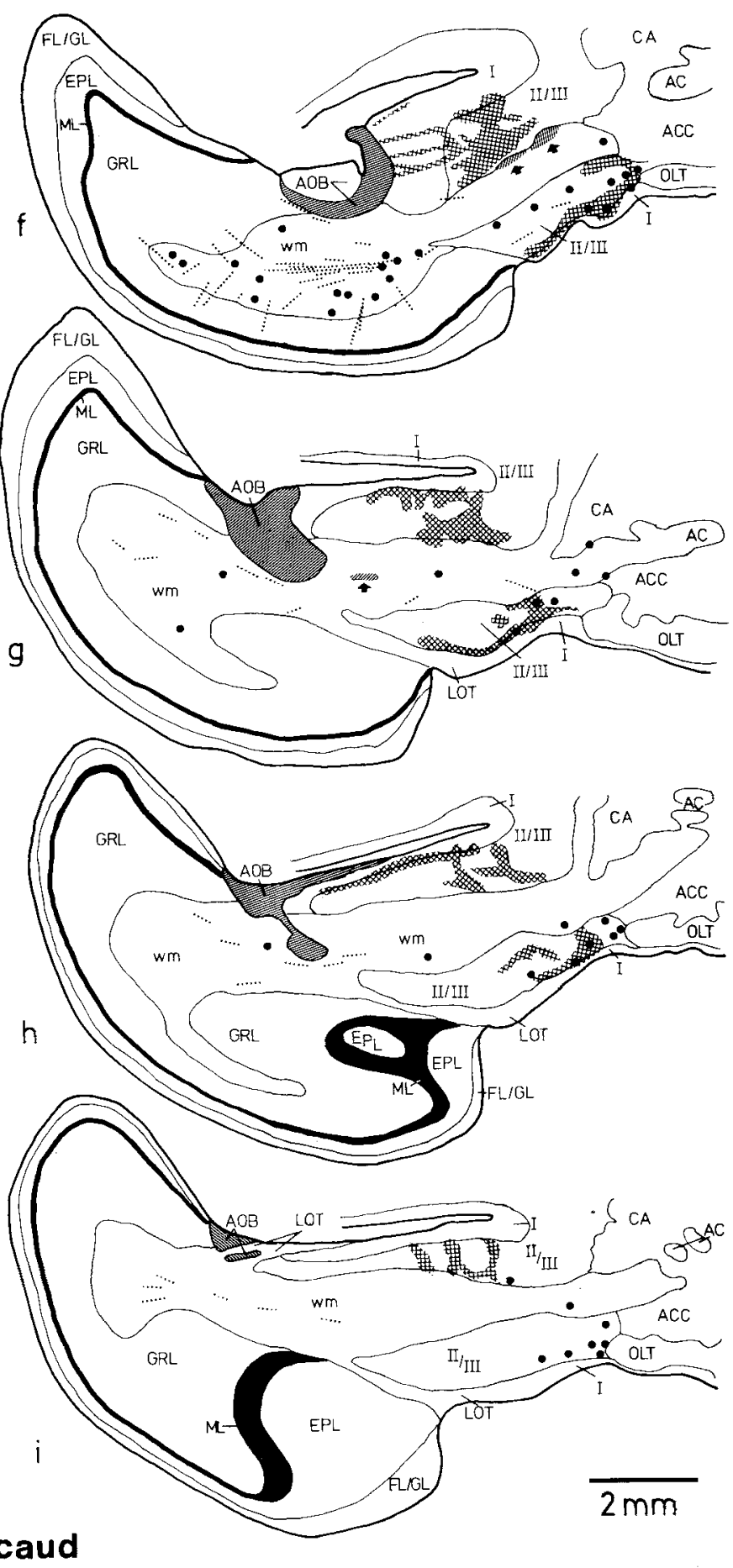

Figure $9 \mathrm{~b}$. Dotted rules indicate the course of the immunoreactive afferent fibers. Checkered patches represent dense terminal fields (as shown in Fig. 9 a,c); hatched areas indicate the AOB and associated granule cell islands (indicated by arrows).
Fig. 9. Camera lucida drawings of SP-ir terminal fields in the olfactory peduncle. Section a corresponds to plane e, section $\mathrm{c}$ to plane $\mathrm{i}$ in Figure 10. Large dots represent immunoreactive neurons of the type shown in $b$ and in Figure $7 \mathrm{~h}$. Small dots represent immunoreactive retrobulbar granule cells. Arrows in c point to finger-like terminal fields. b: Morphology of a SP-ir neuron in the septo-olfactory junction. Arrow points to the axon. 

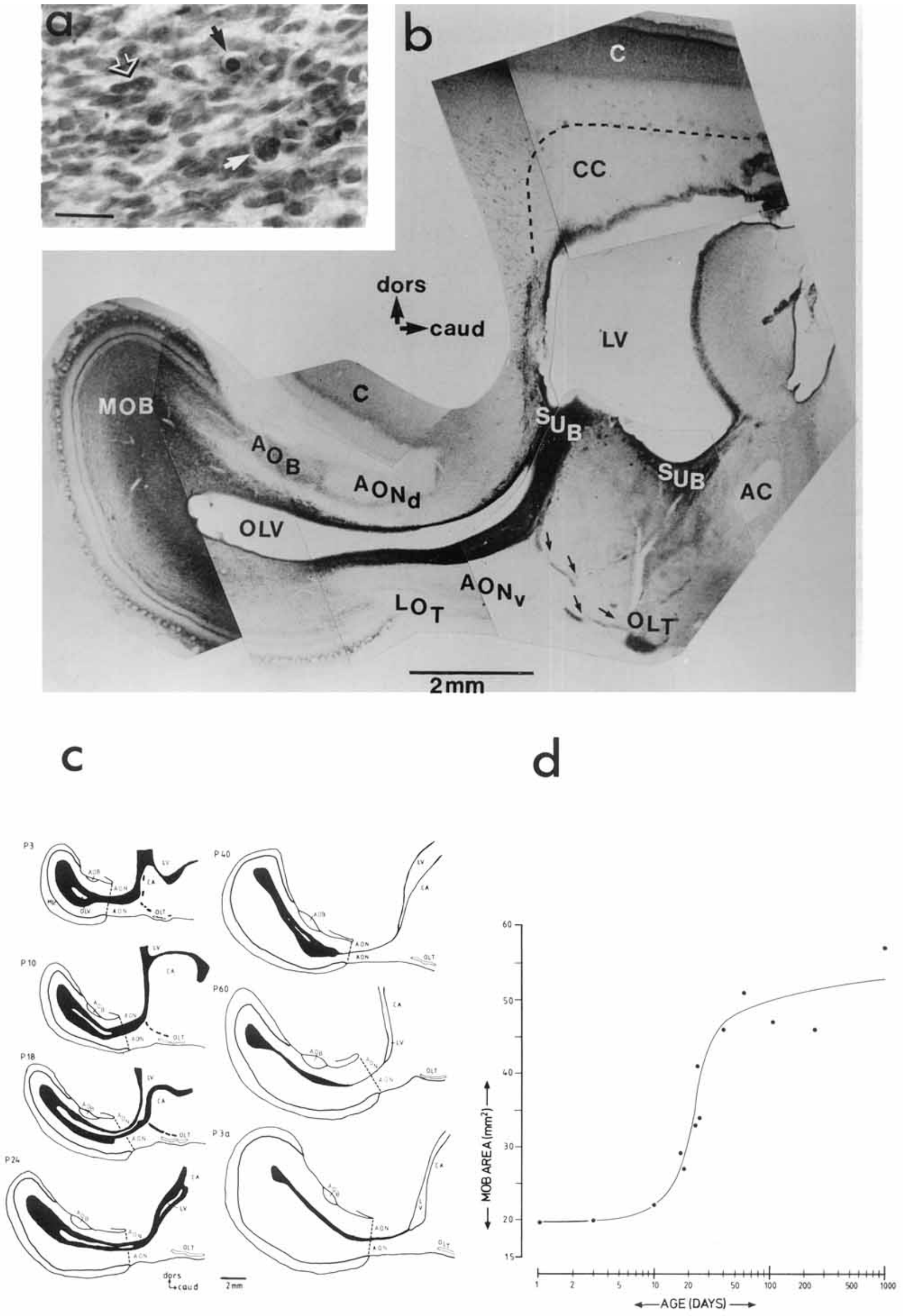

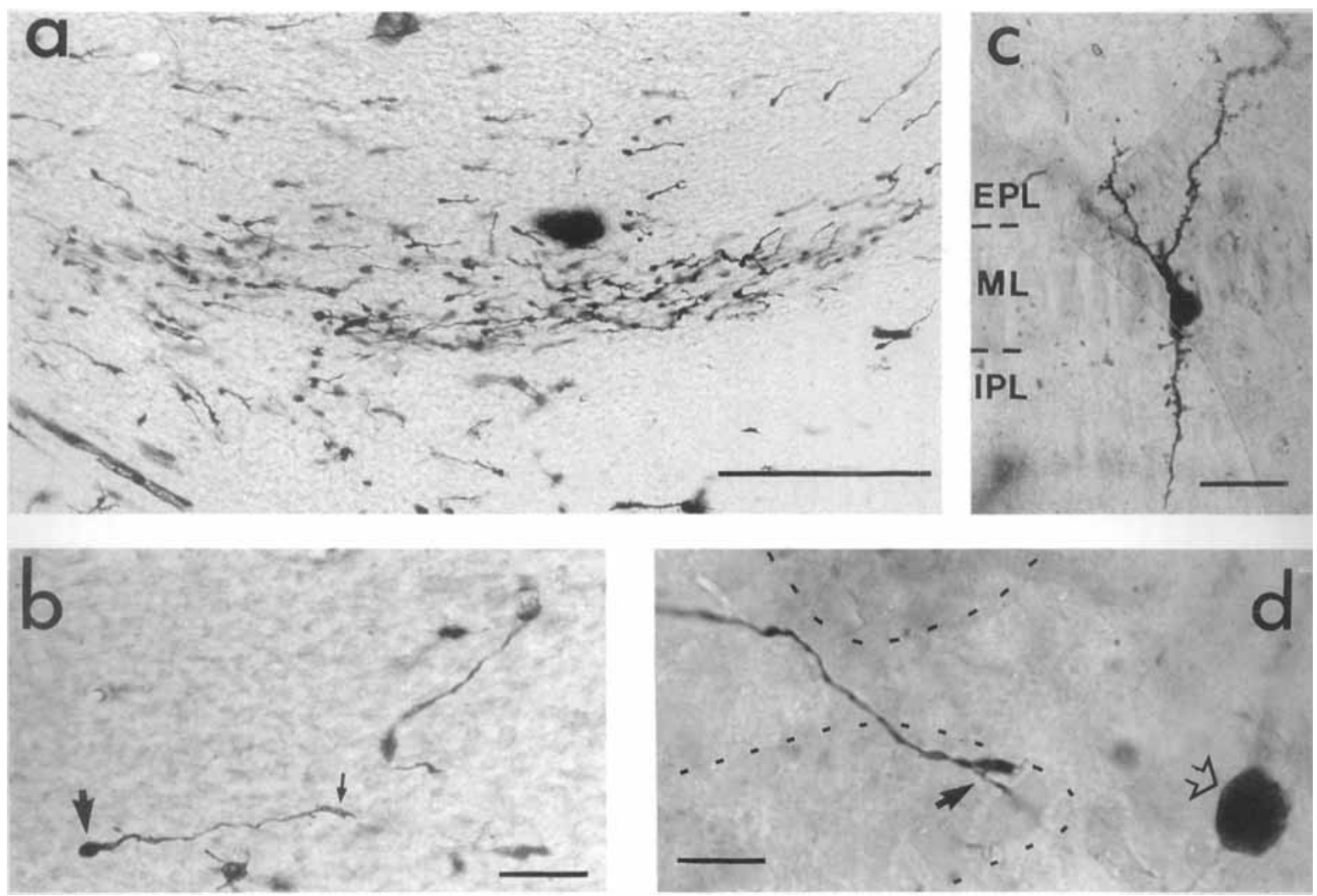

Fig. 12. Postnatal development of the kitten MOB in Golgiimpregnated and immunohistochemical material. a c c: Golgi material of a P 3 kitten. a: Stream of subependymal cells migrating along the ventricle towards the MOB. b: Subependymal cell (arrow) at higher magnification. Its anteriorly oriented process is tipped by a growth cone (small arrow). c: Well differentiated granule cell in the ML. Layers are indicated; photomontage. d: SP-ir material of a P10 kitten. Ingrowing afferent axon passes two granule cell clusters (outlined by dashes). Arrow points to the fiber's growth cone, open arrow to an immunoreactive granule cell soma. Bars: $200 \mu \mathrm{m}$ in a; $20 \mu \mathrm{m}$ in b,c; $10 \mu \mathrm{m}$ in d.
NPY-ir plexuses, and accumulate (partly in patches) predominantly in medial aspects of the olfactory peduncle. The more lateral parts of the AON are less densely innervated, as is the piriform cortex. In contrast, the NPY-ir system is quite homogeneous in medial and lateral AON (SanidesKohlrausch and Wahle, '90a; Fig. 5b) and the fiber density does not markedly change towards the piriform cortex. Also the VIP/PHI-ir neuron system is similar in AON and piriform cortex. Therefore, we tentatively suggest that the SP-ir and opioid-ir innervation is a marker for the AON proper. The projections of the septo-olfactory junction neuron system might reach all those divisions of the olfactory peduncle which have similar functions. The innervation density clearly decreases at a transition from lateral AON to piriform cortex. Such a transition is hardly visible in thionine-stained sections. The finger-like extensions of the SP-ir plexus shown in Figure 10 may well represent columns of neurons which still belong to the AON in terms of function, but are intercalated with extensions of the piriform cortex.

Another major difference between the SP-ir/opioid-ir and the NPY-ir neuron systems concerns the caudal projection. During development, NPY-ir axons bundle up in the olfac= tory limb of the anterior commissure and project via the anterior commissure to the contralateral bulb. In contrast, we have no evidence for a similar projection pattern of $\mathrm{SP}$-ir/opioid-ir axons. Rather it seems that the latter neuron system(s) remains ipsilaterally, and may project through the septo-olfactory junction and taenia tecta into the septal complex. Gall and Moore ('84) have described conspicuous SP-ir and opioid-ir pericellular terminals in the septum which in part are of afferent origin. These terminals are quite similar to those observed in the AON (present study).

Besides the septo-olfactory junction neuron system, we can not exclude additional SP-ir and opioid-ir afferents of di- and mesencephalic origin. For example, a SP-ir projec-
Fig. 11. Postnatal development of the kitten MOB in Nissl stained material. a: Subependymal layer at high magnification shows a mitotic cell (white arrow), a pycnotic cell (dark nucleus, surrounded by the halo of the "empty" soma; black arrow), and a dividing cell (open arrow). Bar: $10 \mu \mathrm{m}$. b: Photomontage of a Nissl stained parasagittal forebrain section of a P 3 kitten. Note the subependymal layer surrounding the olfactory and lateral ventricle. A narrow streak of subependymal cells course towards the olfactory tubercle (arrows). c: Drawings of parasag- ittal Nissl stained sections of the plane comparable to the one shown in $\mathrm{b}$ at different postnatal ages. The subependymal layer is represented in black. Note that bulbar area enlarges enormously and the subependymal layer becomes reduced with age. d: Bulbar area plotted over age. The caudal border of the area measured is indicated by the dashed rules in c. Note that abscissa (age) is logarithmic and ordinate (bulbar area in $\mathrm{mm}^{2}$ ) is linear. 

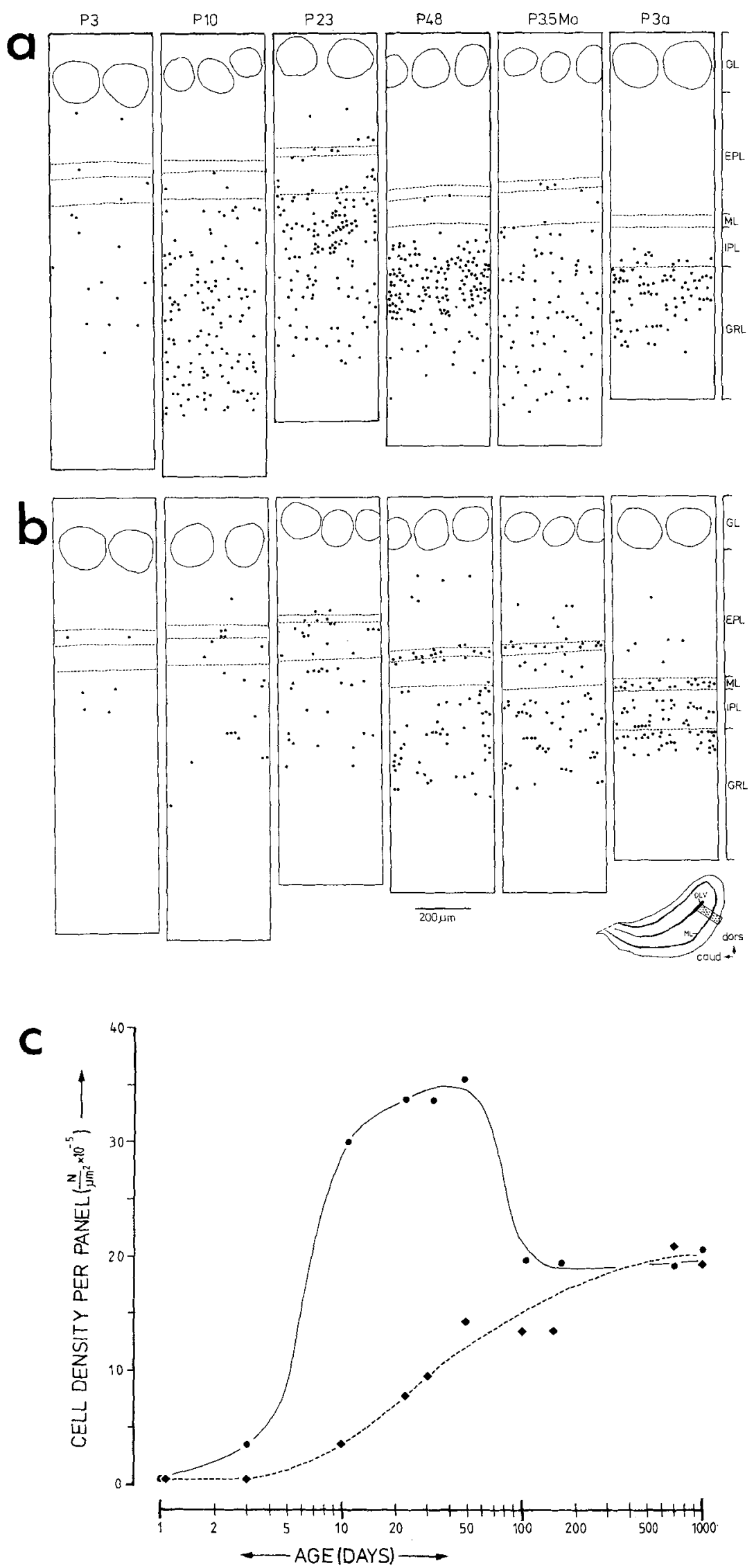

Figure 13 

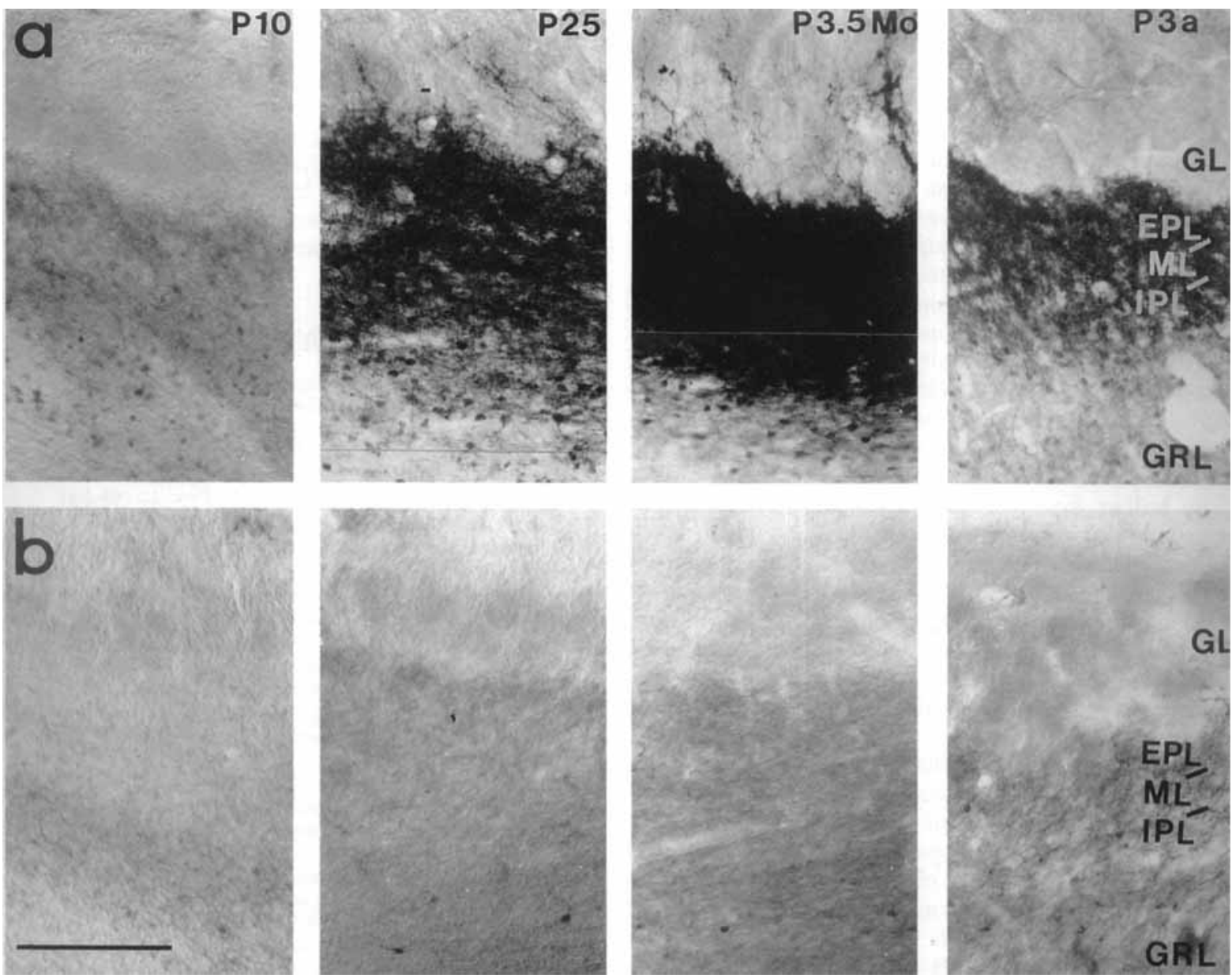

Fig. 14. Photographic documentation of postnatal development of SP-ir (a) and opioid-immunoreactivity $(\mathbf{b})$ in the cat AOB. Ages are indicated in a, layers in a and b. Note the exuberant immunoreactivity in the GL in a (P 25 and P 3.5 months) Bar: $200 \mu \mathrm{m}$.

tion from the brainstem reticular formation to the medial frontal cortex has been described by Vincent et al. ('83). It is possible that some afferent fibers scatter into the adjacent AON or overlap in lateral AON/piriform cortex with the projection of the septo-olfactory junction neuron system.

The serotoninergic projections to the telencephalon terminate in form of pericellular nests (Gall and Moore, '84; Mulligan and Tork, '88) similar to the SP-ir fibers in the

Fig. 13. Changes of SP-ir and opioid-ir granule cell density during postnatal development. a,b: Neurons are plotted in six representative panels through all bulbar layers taken from a median sagittal section (boxed area in the small scetch) of animals at the ages indicated. The postnatal increase in SP-ir (a) and opioid-ir (b) granule cell density is evident. c: Changes in granule cell density plotted over age. SP-ir granules, dots and continuous rule; opioid-ir granules, rhombs and dashed rule. Note that abscissa (age) is logarithmic, ordinate (cell density) is linear. Granule cell density was determined from panels as shown in $a$ and $b$. Granule cell number $\mathrm{N}$ was counted from every panel, respectively. All panels were $400 \mu \mathrm{m}$ wide. Panel length varied and was measured from the pial surface to the wall of the olfactory ventricle (young kitten) or the ventricular ependyma (older animals). Section thickness was constant with $80 \mu \mathrm{m}$. So, cell density was calculated as cell number per panel area $\left(\mathrm{N} / \mu \mathrm{m}^{2}\right)$.
AON and medial frontal cortex (shown in the present study), and in the gyrus cinguli (Wahle, unpublished). It has been suggested, that SP is present in serotoninergic afferents from the raphe nuclei to olfactory centers (Macrides and Davis, '83), because SP and serotonin are colocalized in some raphe subdivisions (Chan-Palay, '79; Lovick and Hunt, '83). However, raphe neurons containing both transmitters have been described only to project to the spinal cord. Ascending raphe projections containing both transmitters remain to be established.

\section{Postnatal development of MOB and AOB}

In Nissl stained material of the kitten MOB, the wall of the olfactory ventricle is surrounded by a thick, darkly stained layer which we identified as subependymal layer. This layer is still mitotic during early postnatal life generating bulbar interneurons, in particular granule cells (Altman, '69; Bayer, '83). The newborn granule cells are added to the GRL (Frazier-Cierpial and Brunjes, '89). We expected to find immature granule cells. 'The Golgi method revealed a subependymal layer full of very small neurons with processes tipped by growth cones. They give the impression of migratory cells. Furthermore, immature and differentiating granule cells can be observed in the granule cell layer, 
and, as early as P 3, fully differentiated granule cells were present, confirming data of Kishi ('87). Subependymal cells and migrating granule cells express the neuronal microtubule associated protein. However, they were not labeled by using neuropeptide immunohistochemistry, and we did not observe immature opioid-ir and SP-ir granule cells in the granule cell layer. The neurons stained look mature. We therefore conclude that opioids and SP are not expressed at detectable levels by either migrating or differentiating granule cells. Apparently, only mature granule cells contain the peptides. It would follow that the postnatal increase of immunoreactive granule cell somata reflects the numerical increase of differentiated granule cells. The development of SP-ir and opioid-ir granule cells thus resemble tyrosine hydroxylase (TH)-ir periglomerular cells of the rat $\mathrm{MOB}$, which start to express TH after they have accomplished differentiation and synaptogenesis (McLean and Shipley, '88). The bulbar interneurons, however, differ from the bulbar/peduncular NPY-ir neurons (Sanides-Kohlrausch and Wahle, '90a) and from peptidergic neurons of the kitten neocortex (Wahle and Meyer '87), which start peptide synthesis in an early stage of morphological differentiation.

In newborn kitten and in adult cats the number of SP-ir granule cells equals the number of opioid-ir granule cells. However, during the first postnatal weeks the proportion of SP-ir granule cells by far exceeds the proportion of opioid-ir cells. Given the above assumptions it appears that granule cells of the GRL proper mature faster than the more superficially located opioid-ir granule cells. Later in development, part of the granule cell population is lost. We could not determine whether the observed decrease in SPexpressing neuron density is caused by a selective loss of SP-ir granule cells in the GRL due to cell death, or by a down-regulation of the peptide in part of the population. Further, we can only speculate about the functional significance of the differential regulation of the peptidergic granule cell populations. For example, it is known that both peptides have counteracting trophic actions. SP stimulates outgrowth of neurites (Narumi und Fujita, '78; Nilsson et al., '85), while opioid peptides inhibit dendritic growth (Hauser et al., '89). It is thus possible that during development a growth stimulating action is required, which later on is successively balanced by a growth inhibitory action. However, such an assumption would only account for the cat $\mathrm{MOB}$, since in rodents only few granule cells express detectable levels of SP, and external tufted cells do not show a developmental regulation of SP-expression (Matsutani et al., '88). In cats, the decrease correlates in time with the prey-imprinting phase in carnivores (Leyhausen, '75), granule cell spine reduction (Apfelbach, '86), and loss of contralateral NPY input (Sanides-Kohlrausch and Wahle, '90a).

The immunoreactive structures in the cat AOB develop quite similar to the cat MOB. However, peptide immunoreactive granule cells appear somewhat earlier. The earlier onset of AOB maturation could be explained by the earlier genesis of AOB neurons (Bayer, '83). Later on, the SP-ir innervation forming in $\mathrm{EPL} / \mathrm{ML} / \mathrm{IPL}$ is much more intense than in the MOB EPL, with processes transiently extending into the GL. Compared to the rat AOB, neither SP-ir mitral cells nor staining only of half the AOB (Matsutani et al., '88; own observations in rat material) were observed during early postnatal life.

\section{ACKNOWLEDGMENTS}

We thank Prof. M. Tohyama and Prof. T. Hamaoka (Dept. Oncology, Cancer Institute, Osaka University Medical School, Osaka, Japan) for providing us with the excellent anti-substance P antiserum and Prof. Dr. A. Herz and Dr. C. Gramsch (Dept. Neuropharmacology, Max-PlanckInstitute for Psychiatry, Martinsried, F.R.G.) for generous supply with the monoclonal antibody 3E7. Supported by Deutsche Forschungsgemeinschaft Schwerpunkt "Verhaltensontogenie."

\section{LITERATURE CITED}

Altman, J. (1969) Autoradiographic and histological studies of postnatal neurogenesis. IV. Cell proliferation and migration in the anterior forebrain with special reference to persisting neurogenesis in the olfactory bulb. J. Comp. Neurol. 137:433-458

Apfelbach, R. (1986) Imprinting on prey odors in ferrets Mustela putoris $f$. furo $L$. and its neural correlates. Behav. Proc. 12:363-381.

Baker, H. (1986) Species differences in the distribution of Substance $P$ and Tyrosine Hydroxylase immunoreactivity in the olfactory bulb. J. Comp. Neurol. 252:206-226.

Bayer, S.A. (1983) ${ }^{3}$ H-Thymidine-radiographic studies of neurogenesis in the rat olfactory bulb. Exp. Brain Res. 50:329-340.

Berman, A.L., and E.G. Jones (1982) The thalamus and basal telencephalon of the cat. A cytoarchitectonic atlas with stereotaxic coordinates. 1. ed. Madison, Wisconsin: The University of Wisconsin.

Bogan, N., N. Brecha, C. Gall, and H.J. Karten (1982): Distribution of Enkephalin-like immunoreactivity in the rat main olfactory bulb. Neuroscience 7:895-906.

Breipohi, W., A. Mackay-Sim, D. Grandt, B. Rehn, and C. Darrelmann (1986) Neurogenesis in the vertebrate main olfactory epithelium. In Breipohl, W. (ed): Ontogeny of Olfaction. Berlin, Heidelberg, New York: Springer Verlag. pp. 23-33.

Buhl, E.H., und J. Lübke (1989) Intracellular Lucifer Yellow injection in fixed brain slices combined with retrograde tracing light and electron microscopy. Neuroscience 28:3-16.

Burd, G.D., Davis, B.J., and F. Macrides (1982) Ultrastructural identification of Substance P immunoreactive neurons in the main olfactory bulb of the hamster. Neuroscience 7:2697-2704.

Cajal, S.R. (1911) Histologie du Systeme Nerveux de L'Homme et des Vertèebrès: II. Paris: Maloine. Reimpress, Madrid: Instituto Cajal, 1955.

Chan-Palay, V. (1979) Combined immunocytochemistry and autoradiography alfter in vivo injections of monoclonal antibody to substance $P$ and ${ }^{3} \mathrm{H}$-serotonin: Coexistence of two putative transmitters in single raphe cells and fiber plexuses. Anat. Embryol. 156:241-254.

Davis, G.J., G.D. Burd, and F. Macrides (1982) Localization of MethionineEnkephalin, Substance P, and Somatostatin immunoreactivities in the main olfactory bulb of the hamster. J. Comp. Neurol. 204:377-383.

Frazier-Cierpial, L., and P.C. Brunjes (1989) Early postnatal cellular proliferation and survival in the olfactory bulb and rostral migratory stream of normal and unilaterally odor-deprived rats. J. Comp. Neurol. 289:481-492.

Gall, C.M., S.H.C. Hendry, K.B. Seroogy, E.G. Jones, and J.W. Haycock (1987) Evidence for coexistence of GABA and Dopamine in neurons of the rat olfactory bulb. J. Comp. Neurol. 266:307-318.

Gall, C.M., and R.Y. Moore (1984) Distribution of enkephalin, substance P, tyrosine hydroxylase, and 5-hydroxytryptamine immunoreactivity in the septal region of the rat. J. Comp. Neurol. 225:212-227.

Gramsch, C., T. Meo, G. Riethmüller, and A. Herz (1983) Binding characteristics of a monoclonal $\beta$-endorphin antibody recognizing the $\mathrm{N}$-terminus of opioid peptides. J. Neurophysiol. 40:1220-1226.

Graziadei, P.P.C., and G.A. Monti-Graziadei (1979) Neurogenesis and neuron regeneration in the alfactory system of mammals. I. Morphological aspects of differentiation and structural organization of the olfactory neurons. J. Neurocytol. 8:1-18.

Greer, C.A. (1987) Golgi Analyses of dendritic organization among denervated olfactory bulb granule cells. J. Comp. Neurol. 257:442-452.

Halász, N., and G.M. Shepherd (1983) Neurochemistry of the vertrebrate olfactory bulb. Neuroscience 10:579-619.

Harlan, R.E., M.M. Garcia, and J.E. Krause (1989) Cellular localization of Substance $P$ - and Neurokinin A-encoding preprotachykinin mRNA in the female rat brain. J. Comp. Neurol. 287:179-212. 
Hauser, K.F., P.J. McLaughlin, and I.S. Zagon (1989) Endogenous opioid systems and the regulation of dendritic growth spine formation. $J$. Comp. Neurol. 281:13-22.

Katz, L.C. (1987) Local circuity of identified projection neurons in cat visual cortex brain slices. J. Neuroscience 4:1223-1249.

Kishi, K., K. Mori, and H. Ojima (1984) Distribution of local axon collaterals of mitral, displaced mitral, and tufted cells. J. Comp. Neurol. 225:511526.

Kishi, K. (1987) Golgi studies on the development of granule cells of the rat olfactory bulb with reference to migration in the subependymal layer. $J$. Comp. Neurol. 258:112-124.

Kosaka, T.H. Yoshihiro, K. Hama, I. Nagatsu, and J.-Y. Wu (1985) Coexistence of immunoreactivities for glutamate decarboxylase and tyrosine hydroxylase in some neurons in the periglomerular region of the rat main olfactory bulb: possible coexistence of gamma-aminobutyric acid (GABA) and dopamine. Brain Res. 343:166-171.

Ljungdal, A.A., T. Hökfelt, and E. Nilsson (1978) Distribution of Substance P-like immunoreactivity in the central nervous system of the rat. I. Cell bodies and nerve terminals. Neuroscience 3:861-943.

Leyhausen, P. (1975) Verhaltensstudien an Katzen. 4. Aufl. Berlin, Hamburg: Paul Parey.

Lohman, A.H.M. (1963) The anterior olfactory lobe of the guinea pig. A descriptive and anatomical study. Acta Anat. (Basel) 53(Suppl. 49):1109.

Lovick, T.A., and S.P. Hunt (1983) Substance P immunoreactive and serotonin-containing neurons in the ventral brainstem of the cat. Neurosci. Lett. 36:223-228.

Macrides, D, and B. Davis (1983) The olfactory bulb. In P.C. Emson (ed): Chemical Neuroanatomy. New York: Raven, pp. 391 -426

Macrides, F., and S.P. Schneider (1982) Laminar organization of mitral and tufted cells in the main olfactory bulb of the adult hamster. J. Comp. Neurol. 208:419-430.

Matsutani, S., E. Senba, and M. Tohyama (1988) Neuropeptide- and Neurotransmitter-related immunoreactivities in the developing rat olfactory bulb. J. Comp. Neurol. 272:331-342.

Matsutani, S., E. Senba, and M. Tohyama (1989) Distribution of neuropeptidelike immunoreactivities in the guinea pig olfactory bulb. J. Comp. Neurol. 280:577-586

McLean, J.H., and M.T. Shipley (1988) Postmitotic, postmigrational expression of tyrosine hydroxylase in olfactory bulb dopaminergic neurons. J. Neuroscience 10:3658-3669.

Meyer, G. (1983) Axonal patterns and topography of short-axon neurons in visual areas 17, 18, and 19 of the cat. J. Comp. Neurol. 220:405-440.

Meyer, G., and P. Wahle (1986) The olfactory tubercle of the cat. I. Morphological components. Exp. Brain Res. 62:515-527.

Mori, D., K. Kishi, and H. Ojima (1983) Distribution of dendrites of mitral, displaced mitral, tufted and granule cells in the rabbit olfactory bulb. J. Comp. Neurol, 219:339-355.

Mulligan, K.A., and 1. Törk (1988) Serontoninergic Innervation of the cat cerebral cortex. J. Comp. Neurol. 270:86-110.
Narumi, S., and T. Fujita (1978) Stimulatory effects of substance P and nerve growth factor (NGF) on neurite outgrowth in embryonic chick dorsal root ganglia. Neuropharmacology 17:73-76.

Nilsson, J., A.M. von Euler, and C.-J. Dalsgaard (1985) Stimulation of connective tissue cell growth by substance $P$ and substance K. Nature 315:61-62.

Orona, E., J.W. Scott, and E.C. Rainer (1983) Different granule cell populations innervate superficial and eep regions of the external plexiform layer in the rat olfactory bulb. J. Comp. Neurol. 217:227-237.

Pinching, A.J., and T.P.S. Powell (1971a) The neuron types of the glomerular layer of the olfactory bulb. J. Cell Sci. 9:305-345.

Pinching, A.J., and T.P.S. Powell (1971b) The netropil of the glomeruli of the olfactory bulb. J. Cell Sci. 9:347-377.

Price, J.L., and T.P.S. Powell (1970) The morphology of the granule cells of the olfactory bulb. J. Cell Sci. 7:91-123.

Purves, D., A.-S. LaMantia, and S.L. Pomeroy (1989) Addition of functional neuronal assemblies visualized in the olfactory bulb of living mice. Soc. Neurosci. Abstr. 15 1:325.8:809.

Ribak, C.E., J.E. Vaughn, K. Saito, R. Barber, and E. Roberts (1977) Glutamate decarboxylase localization in neurons of the olfactory bulb. Brain Res. 126:1-18.

Sanides-Kohlrausch, C, and P. Wahle (1990a) Morphology of Neuropeptide-Y immunoreactive neurons in the cat olfactory bulb and olfactory peduncle: Postnatal development and species comparison. J. Comp. Neurol. 291:468-489

Sanides-Kohlrausch, C., and P. Wahle (1990b). VIP- and PHI-immunoreactivity in olfactory centers of the adult cat. J. Comp. Neurol. 294: 325-339.

Schneider, S.P., and F. Macrides (1978) Laminar distribution of interneurons in the main olfactory bulb of the adult hamster. Brain Res. Bull. 3:73-82

Shults, C.W., R. Quirion, B. Chronwall, R.N. Chase, and T.L. O'Donohue (1984) A comparison of the anatomical distribution of substance $\mathbf{P}$ and substance $P$ receptors in the rat central nervous system. Peptides 5:1097-1128.

Switzer, R.C. J.I. Johnson, and J.A.W. Kirsch (1980) Phylogeny through brain traits. Relation of lateral olfactory tract fibers to the accessory olfactory formation as a palimsest of mammalian descent. Brain Behav. Evol. 17:339-363.

Takatsuki, K., Y. Kawai, M. Sakanaka, S. Shiosaka, E. Senba, and M Tohyama (1983) Experimental and immunohistochemical studies concerning fibers in the lateral lemniscus and lateral parabrachial area of the rat, including the fiber pathways. Neuroscience 1:57-71.

Vincent, S.R., K. Satoh, D.M. Armstrong, and H.C. Fibiger (1983) Substance $P$ in ascending cholinergic reticular system. Nature 306:688-691.

Wahle, P., and G. Meyer (1987) Morphology and quantitative changes of transient NPY-ir neuronal populations during early postnatal development of the cat visual cortex. J. Comp. Neurol. 261:165-192.

Warden, M., and W.S. Young, III (1988) Distribution of cells containing mRNAs encoding Substance $\mathrm{P}$ and Neurokinin $\mathrm{B}$ in the rat central nervous system. J. Comp. Neurol. 272:90-113. 